\title{
Çocuk ve Gençlik Sanat Müzesinin Görsel Sanatlar Eğitimine Katkısı ${ }^{1}$
}

\author{
Şahika YAMAN BAYRAM \\ Gazi Üniversitesi \\ yamansahika@gmail.com
}

Gönderilme Tarihi: 16/07/2019

Kabul Tarihi: 22/11/2019

Yayınlanma Tarihi: 30/11/2019

DOI: 10.30855 /gjes.2019.05.03.003

\begin{tabular}{l} 
Makale Bilgileri \\
\hline Anahtar Kelimeler: \\
Çocuk ve gençlik, \\
Sanat müzesi, \\
Sanat eğitimi, \\
Müze eğitimi
\end{tabular}

ÖZET

Bu araştırmanın amacı; Türkiye' de yeni bir kavram olan Çocuk ve Gençlik Sanat Müzelerinin görsel sanatlar eğitimine katkısını ders öğretmenlerinin görüşleri doğrultusunda araştırmaktır. Bu doğrultuda araştırmada nitel araştırma yöntemleri olarak; Veri toplama yöntemlerinden durum çalışması yapılmıştır. Araştırma yöntemlerinden Literatür taraması modeli ve yarı yapılandırılmış görüşme yöntemi uygulanmıştır. Buna bağlı olarak konu ile ilgili dünyada bulunan örnekleri ve ülkemizde benzer uygulamaları araştırılarak alansal çıkarımlarda bulunulmuştur. Konya'nın Ereğli ilçesinde Millî Eğitim Bakanlığına bağlı okullarda Görsel Sanatlar öğretmeni olarak görev yapan 21 öğretmen ile görüşmeler gerçekleştirilmiştir. Yarı yapılandırılmış form ile görüşmelerden elde edilen nitel veriler içerik analizine tabi tutulmuştur. Araştırmada, müze eğitiminin verilmesi konusunda eksiklikler saptanıp, öğretmenlerin öğrencileri müzeye götürme oranlarının az olduğuna; müzede sanat eğitiminde kavramsal ve uygulama çalışmalarını az oranda gerçekleştirdikleri sonucuna varılmıştır. Fakat müze eğitiminin gerekliliği, ülkemizde var olmayan Çocuk ve Gençlik Sanat Müzelerinin olası kazanımları ve bu kazanımların sanat eğitimine katkısı hususunda ilgili literatürleri destekleyen söylemlerde bulunmuşlardır. Çocuk ve Gençlik Sanat Müzesinin; çocuklara, gençlere ve öğretmenlere olumlu yönde kazanımlar sağlayacağı ve sanat eğitimine kayda değer katkı sağlayacağı sonucuna varılmıştır.

\footnotetext{
${ }^{1} \mathrm{Bu}$ çalışma yazar tarafından hazırlanan yüksek lisans tezinden üretilmiştir.

Yaman Bayram, Ş. (2019). Çocuk ve gençlik sanat müzesinin görsel sanatlar eğitimine katkisi. Gazi Eğitim Bilimleri Dergisi, 5(3), 32-66. DOI: https://dx.doi.org/110.30855/gjes.2019.05.03.003
}

Dergi Web Sayfasi: http://dergipark.gov.tr/gebd 


\section{Contribution of Children and Youth Art Museum to Visual Arts Education}

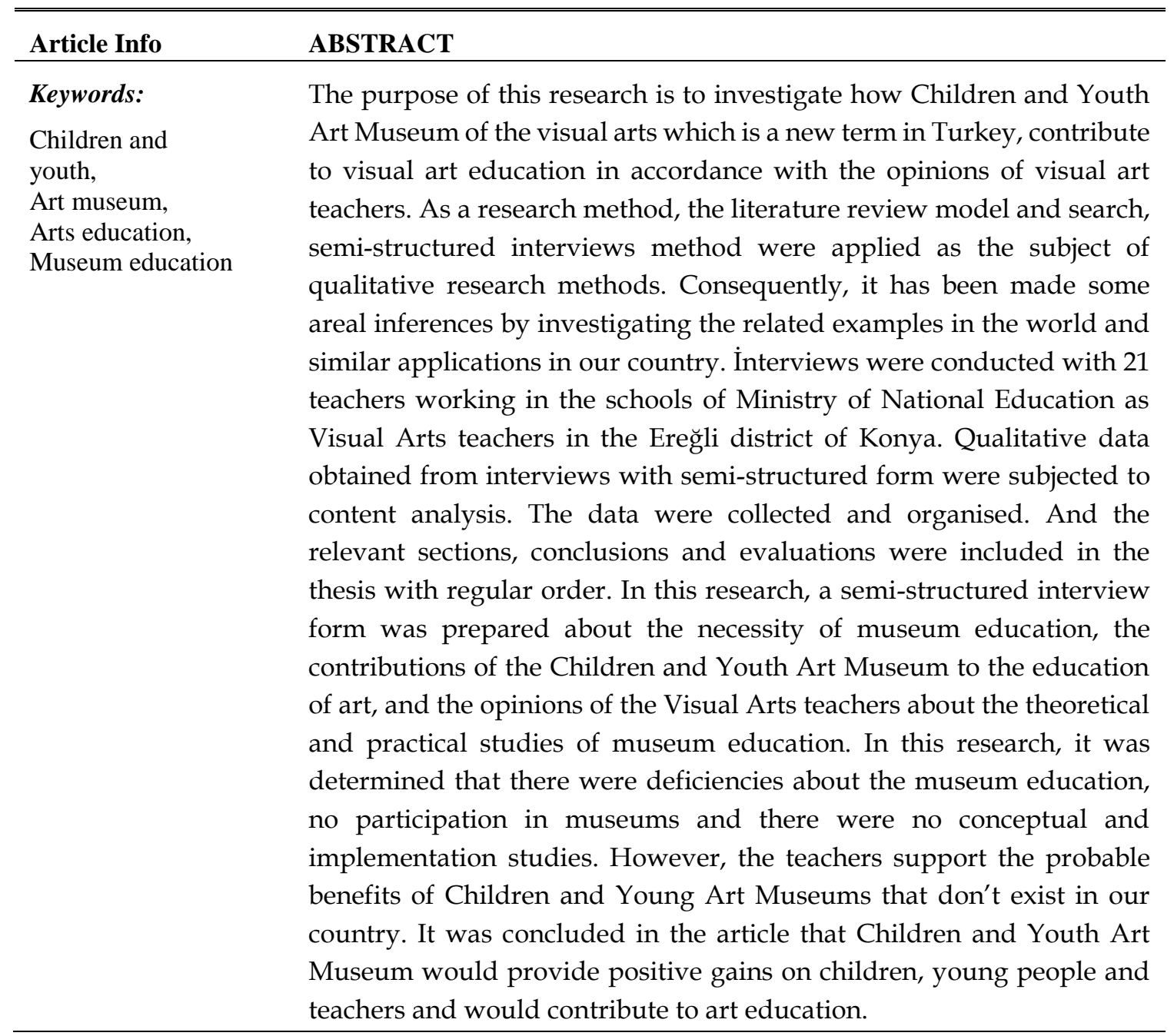

\section{GİRIŞ}

İnsanoğlu geçmişini hep merak eden ve sorgulayan bir varlıktır. Tarih, bize zamanın izlerini; geleceğin hislerini yansıtır. Müzeler topraklarda yaşanılan savaşı, toplumsal değişimi, sanatı, kültürü insanın var olduğu andan iltibaren gelişimini açıkça gösterir. Toplumsal açıdan müzenin görevleri oldukça fazladır. Günümüzde müzeler, sanatı, bilimi, geleceğin tarihini, teknolojiyi ve doğaya ait alanlarda geçmişin, geleceğin izlerini dört duyu ile yaşayarak öğrenmenin gerçekleşeceği, herkese açık, heyecan verici öğrenme alanıdır (Buyurgan ve Buyurgan, 2012, s. 68). Günümüz okullarında görsel sanatlar dersinin haftada bir ders saati olmasından ve şehirlerde düzenlenen sergilerin az olmasından dolayı görsel sanat kültürü bakımından eksik kalmaktayız.

Öğrenciler sanatı sadece medyada, büyük şehirlerde ve derste gördükleri ile sınırlandırmaktadırlar. Çocukların, gençlerin hatta yetişkinlerin etkin rol almalarının dokun-yap, 
hissetme, eğlenme, etkileşim ve yaşamayla öğrenme yöntemiyle, sanatın önemini anlamaları ve aslında sadece gezerek değil keşfederek keyifli hale gelmesinde önemli rol oynayan Çocuk ve Gençlik Sanat Müzelerinin yaratıcı potansiyellerini artıracağı düşünülmektedir. Eğitim öğretimde çağdaş öğrenmelerin gerçekleşeceği ve farklı yöntemlerin uygulanacağı kurum olarak artık müzelerin kullanımının yaygınlaşması önem arzetmektedir (Karadeniz, 2009).

Sanat müzeleri, sanat eğitimi açısından oldukça önem taşımaktadır. Ülkemizde müzeler sıkıcı, sadece gezip görmekle sınırlı bilinmektedir. Gençler ve çocuklar, okul dışında müze gibi yerlerde de zaman geçirilebileceğini bilmemektedir. Sanat eğitimi; atölyeler, galeriler, okullar dışında çocuk ve gençlik sanat müzelerinde etkinlikler ile verilen estetik algı, sanat tarihi, görsel kültür bakımından önemlidir.

Dünyada ki örneklerden yola çıkarak Çocuk ve Gençlik Sanat Müzelerinin görsel sanatlar eğitimine katkısının oldukça fazla olduğu görülmüştür. Öğrencilerin sanat eserlerini birebir görerek ve esinlenerek çalışması eğitimin kalıcılığı bakımından önemlidir. Sanat müzelerinde bulunan eserlerin tarihî dokusu, çocuklara sanat tarihi kronolojisini kavratmada yardımcı olacaktır. Bu sayede kalıcı öğrenme sağlanacaktır. Görsel sanat eğitiminde çocukların ve gençlerin soyut ifadelerden ziyade, somut eserlerle karşılaşması, onlara dokunması ve orada etkinlikler yapması görsel sanatlar eğitiminde kalıcılık açısından önemli olacaktır.

$\mathrm{Bu}$ araştırmanın amacı; Türkiye'de yeni bir kavram olan Çocuk ve Gençlik Sanat Müzelerinin görsel sanatlar eğitimine olan katkısını ders öğretmenlerinin görüşleri doğrultusunda araştırmaktır. Bu doğrultuda ülkemizde az bilinen Çocuk ve Gençlik Sanat Müzelerinin sanat eğitimi açısından katkısına yönelik Görsel Sanatlar öğretmenlerinin görüşleri baz alınarak dünyada bulunan örnekler ile tartışılması ve katkısının ortaya çıkartılması düşünülmektedir. Ülkemizde bulunmayan Çocuk ve Gençlik Sanat Müzelerinin görsel sanatlar eğitimine katkısını, müze eğitiminin gerekliliği ve müzede kuramsal ile uygulama çalışmalarının ne düzeyde yapılabilirliği açısından alan öğretmenlerinin görüşleri önem arzetmektedir. Çocuk ve Gençlik Sanat Müzeninin katkılarınıyla ülkemizde alanla ilgili hangi çalışmalar yapılabildiği, Görsel Sanatlar öğretmenlerinin programlarına ne derece dahil edilebildiği ve sanatın eğitiminin temellerini sınıf ortamında ne derece uygulayabildikleri alan için önemlilik arz etmektedir.

\section{YÖNTEM}

Bu araştırma bir nitel araştırmadır. Ülkemizde Çocuk ve Gençlik Sanat Müzesinin var olmamasından dolayı uygulama çalışması yapılamamıştır. Nitel araştırma yöntemlerinden durum çalışması yapılmış bu bağlamda; konu tarama olarak literatür taraması modelinden ilgili dünyada bulunan örnekleri ve ülkemizde benzer uygulamaları araştırılarak alansal çıarımlarda bulunulmuş ve yarı yapılandırılmış görüşme yapılmıştır. Yarı yapılandırılmış form ile 
görüşmelerden elde edilen nitel veriler içerik analizine tabi tutulmuştur. Nitelikli bir görüşme, bireysel düşünceler ve inanışlar hakkında yansız bilgi edinme sanatı ve bilimidir. Görüşmecinin bilgileri, düşünceleri, davranışları bir sistemdir. Görüşmenin amacı, araştırmanın tüm ögelerini araştırmaktır (Büyüköztürk, Çakmak, Akgün, Karadeniz ve Demirel, 2016, s. 153).

\section{Katılımcilar}

Araştırma için hazırlanan görüşme formu katılımcılara sorularak kayıt altına alınmıştır. Katılımcılar; Konya Ereğli'de çalışan Görsel Sanatlar öğretmenleridir. Araştırmanın örneklemi olan öğretmenler için Resmî ve özel okullarda çalışan karma bir grup seçilmiştir. Konu ile ilgili alan araştırması yapılmıştır.

\section{Veri Toplama Araçları}

Veriler kütüphanelerde yer alan kaynaklardan, dünyada bulunan Çocuk ve Gençlik Sanat Müzesi örneklerinden ve alan ile ilgili diğer çalışmalardan elde edilmiştir. Bu alanda Türkiye'de ve farklı ülkelerde yapılan çalışmalar incelenmiştir. Veriler toplanarak ve düzenlenerek ilgili bölümlere, düzenli sıralama ile çıarımlar yapılarak, değerlendirmeler araştırmaya dâhil edilmiştir.

Bu araştırmada Görsel Sanatlar öğretmenlerinin, Çocuk ve Gençlik Sanat Müzesinin sanat eğitimine katkıları yolunda, müze eğitiminde kuramsal ve uygulama çalışmaları hakkında; müze eğitiminin gerekliliğiyle ilgi görüşlerini belirlemek amacıyla bir yarı yapılandırılmış görüşme formu hazırlanmıştır. Hazırlanan bu form, iki uzman tarafından incelenmiş; uzmanların görüş ve önerileri doğrultusunda nihâ̂ haline getirilmiştir. Görüşme formunun hazırlanması için öncelikle; Çocuk ve Gençlik Sanat Müzeleri, müze eğitiminde uygulamaların önemi; müze eğitiminin eğitim programlarında yeri, kazanımları değerlendirerek bu alanda yayımlanan yayınlar incelenmiş ve derlenmiştir. Bu bilgiler ışığında iki ana bölüm oluşturulmuştur. İlk bölümde öğretmenin kişisel bilgilerine yer verilmiş ikinci bölümde "Çocuk ve Gençlik Sanat Müzesi hakkında öğretmenlerin ne derece bilgi sahibi olduğunu”, "Çocuk ve Gençlik Sanat Müzesi ülkemizde olsaydı sanat eğitimine katkısının neler olacağı”, "Çocuk ve Gençlik Sanat Müzesi olsaydı hangi kazanımlar sağlayacağını" ve "Öğretmenlerin müze eğitiminde internetten ne derece yararlandığına" "Müze eğitiminin gerekliliği", "Müzelerde öğrencilere uygulama çalışması yapılabilirliği”, "Müzelerin sanatsal etkinlik alanlarının yeterliliğine” ilişkin görüşleri 9 alt tema olarak belirlenmiştir. Araştırma verilerinin toplanmasına yönelik yapılan yarı yapılandırılmış görüşmeler amacıyla araştırmacı, katılımcıların eğitim verdikleri uygun mekânlarda, randevu alarak uygun zaman dilimlerinde gerçekleştirilmiştir. İzinli öğretmenlerle kamu alanlarında görüşülmüş ve öğretmenlerden bazılarıyla uygun zaman dilimi ayarlanamadığından telefon ile görüşmeler yapılmıştır. Görüşmeler veri kaybı yaşamamak 
amacıyla görüşmecilerden izin alınarak ses kaydına alınmıştır. Bazı görüşmeler yazılı olarak kayıt altına alınmıştır. Görüşmeler ortalama 25 dakika sürmüştür. Katılımcılara araştırmanın amacına yönelik ön bilgilendirme yapılıp "Yaygınlaşması yeni sayılan Çocuk ve Gençlik Sanat Müzesi Hakkında Bilginiz Var mı?" sorusu yönlendirilip, sonrasında bilgisi olmayan öğretmenlere Buyurgan ve Buyurgan (2012) yaptıkları çalışmada yer alan Çocuk ve Gençlik Sanat Müzesi tanımı; "Çocuklar ve gençler için sanatı tanıma, anlama ve sevmelerine yönelik oluşturulmuş müzelerdir. Fizikî özellikler ve etkinlikler yaş grupları göz önünde bulundurularak düzenlenmektedir. Çocuk ve Gençlik Sanat Müzeleri diğer sanat müzelerinden farklı olarak etkinlik bazlı düzenleme ve eserlerin seçimi pedagojik açıdan değerlendirerek düzenlenmiş okul dışı sanat etkinliklerinin yapılmasına uygun yerlerdir." verilerek diğer maddelere yönelik görüşleri istenmiştir. Bütün görüşme notları sırası ile yazılmış ve katılımcılara görüşme sırası ile (K1), (K2) gibi kodlar verilmiştir.

\section{Verilerin Analizi}

Tez konusuyla ilişkin literatür ve kaynaklardan elde edilen veriler ile öğretmen görüşleri içerik analizine tabi tutulmuş çözümlenerek ortak bir bilgi alanı oluşturulmuştur. Bu bilgiler ışığında iki uzman tarafından incelenilen görüşme formu hazırlanmış ve form ile ilgili birimlerden izinler alınarak görüşmelere başlanmıştır. Katılımcıların görüşleri not edilmiş ilgili temalara eklenmiştir. Araştırmada toplanılan veriler düzenlemiş ve seçilen örneklerin içerikleri değerlendirilmiştir. Katılımcı görüşleri dünyada bulunan Çocuk ve Gençlik Sanat Müzelerinin amaçları ve çalışmalarıyla tartışılmıştır. Alan ile ilgili çalışmalar araştırmanın amacına göre sıralanmış ve ilgili bölümlere dahil edilip katılımcı görüşleri ile tartışılarak yorumlanmıştır. Tez çalışması sürecinde elde edilen veriler Çocuk ve Gençlik Sanat Müzesinin görsel sanat eğitimi açısından katkısı irdelenmiştir.

\section{BULGULAR}

Bu bölümde 1. Alt amaç olan öğretmenlerin Çocuk ve Gençlik Sanat Müzelerinin nitelikleri hakkındaki görüşlerinin neler olacağına yönelik katılımcılara sorulan "Yaygınlaşması yeni sayılan Çocuk ve Gençlik Sanat Müzesi hakkında öğretmenlerin ne derece bilgi sahibi olduğu", "Çocuk ve Gençlik Sanat Müzesinin sanat eğitimine katkısı neler olacağı", "Çocuk ve Gençlik Sanat Müzesi hangi kazanımlar sağlayacağı" maddeleri belirtilmiştir. Araştırmanın 2. Alt amacı olarak öğretmenlerin Çocuk ve Gençlik Sanat Müzesinin gerekliliği hakkındaki görüşlerinin neler olduğuna yönelik katılımcılara sorulan "Çocuk ve Gençlik Sanat Müzesinin Gerekliliği” maddesi belirtilmiştir. 3. Alt amaç doğrultusunda öğretmenlerin müzede uygulama çalışmaları yapılması hakkındaki görüşlerine yönelik ise: “Müzelerde öğrencilere ne derece sanatsal uygulama çalışması yaptırabildikleri", "Müzelerin sanatsal etkinlik alanlarının yeterliliği", “Müzede görsel sanat eğitiminde kuramsal ve uygulama çalışmaların getirdiği kazanımlar 
hakkında düşünceleri”, “Öğrencileri müzeye götürmeden müze eğitiminin verilmesini doğru ve yeterli bulup bulmadıkları", buna bağlı olarak "Öğretmenlerin müze eğitiminde internetten ne derece yararlandığı" hakkındaki görüşlerine yer verilmiştir. Öğretmen görüşleri temalar halinde sunulmuştur.

Katılımcılara formun 1. Maddesi olarak "Yaygınlaşması yeni olan Çocuk ve gençlik sanat müzesi hakkında bilginiz var mı?" sorusu sorulmuştur. Katılımcıların cevapları ana temalarda birleştirilmiş ve Şekil 1'de katılımcı görüş sayısına göre yüzdeler alınmış ve gösterilmiştir.

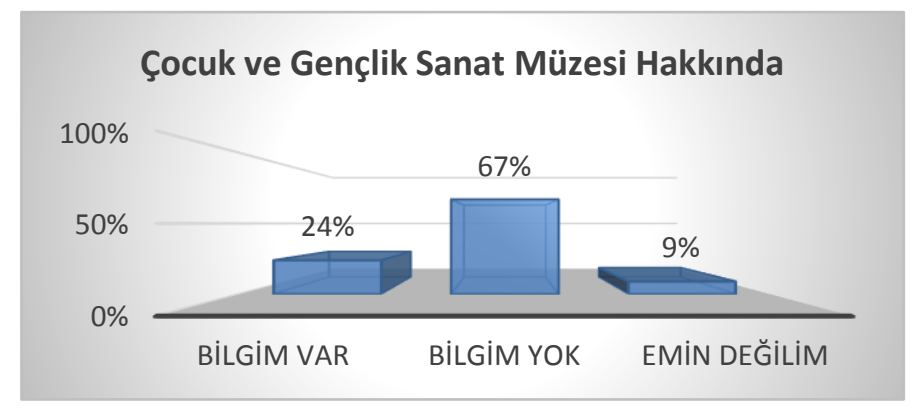

Şekil 1. Çocuk ve Gençlik Sanat Müzesi hakkında katılımcı bilirlik düzeyi (\%)

Şekil 1'de görüldüğü gibi katılımcıların \%9'u "Emin değilim", \%24'ü "Bilgim var" ve \%67'si “Bilgim yok" ifadesini kullanmıştır.

“Emin değilim” ifadesine örnek söylem olarak:

“Duydum sanırım emin değilim, oyuncak müzesi gibi mi?” (K19)

"Bilgim var" ifadesine örnek söylem olarak:

“Amerika'da olan müze sanırım; Boston'da yanlış bilmiyorsam." (K21)

"Bilgim yok" ifadesine örnek söylem olarak:

“ilk defa duyuyorum." (K15)

"Bilmiyorum" ve "Emin değilim" ifadeleri kullanan katılımcılara araştırmanın devamını sağlayabilmek ve araştırmanın ana temalarına ulaşabilmek için Çocuk ve Gençlik Sanat Müzesi tanımı verilmiştir. Bu tanım S. Buyurgan ve U. Buyurgan'ın (2012) yaptıkları çalışmaya göre:

“Çocuklar ve gençler için sanatı tanıma, anlama ve sevmelerine yönelik oluşturulmuş müzelerdir. Fizikî özellikler ve etkinlikler yaş grupları göz önünde bulundurularak düzenlenmektedir. Çocuk ve Gençlik Sanat Müzeleri, diğer sanat müzelerinden farklı olarak etkinlik bazlı düzenleme ve eserlerin seçimi pedagojik açıdan değerlendirerek düzenlenmiş okul dışı sanat etkinliklerinin yapılmasına uygun yerlerdir." 
"Bilgim yok" ve "Emin değilim" ifadeleri kullanan katılımcılara "Çocuk ve Gençlik Sanat Müzesi" tanımı verildikten sonra araştırmanın 2. Maddesi olan “Çocuk ve Gençlik Sanat Müzesi ülkemizde olsaydı sanat eğitimine katkısı neler olurdu?" sorusu yönlendirilmiştir. Cevaplar 38 ana tema etrafında toplanmış ve bu temalara katılımcıların hangi oranla katıldığı yüzdeler olarak saptanmıştır. Bulgular Tablo 1'de gösterilmiştir.

Tablo 1.

Çocuk ve Gençlik Sanat Müzesinin Ülkemizde olsaydı Sanat Ĕ̆itimine Katkısına Yönelik Görüşler

\begin{tabular}{|c|c|}
\hline$(\%)$ & Görüşler \\
\hline 29 & 1. Bireylerin sanata ilgisi artardı. \\
\hline 14 & 2. Bireyler sanatsal teknik olarak bilgi edinirdi. \\
\hline 9 & 3. Bireyler sanatsal terimleri tanirdı. \\
\hline 24 & 4. Öğretmenlere, öğrencilere, toplumun her bireyine sanatsal katkı sağlardı. \\
\hline 4 & 5. Çocukların resimlerde verdiği mesajlar şekil alırdı. \\
\hline 29 & 6. Bireylerin sanata bakış açısı değişirdi. \\
\hline 9 & 7. Bireyler sanat eserini anlamlandırmayı öğrenirdi. \\
\hline 4 & 8. Sanatsal alanda bireyler cüretkâr olurdu. \\
\hline 9 & 9. Bireylerin yeteneklerini keşfetmesine yardımcı olurdu. \\
\hline 9 & 10. Sanat eğitimini yaparak ve yaşayarak öğrenme fırsatı sunardı. \\
\hline 4 & 11. Bireylerin müze bilinci edinmesini sağlardı. \\
\hline 9 & 12. Sanatı seven bireyler olurdu. \\
\hline 4 & 13. Sanatsal bilgi birikimine sahip bireyler olurdu. \\
\hline 14 & 14. Sanata ve sanatçıya saygı duyan toplum olurdu. \\
\hline 4 & 15. Sanat hayatın bir parçası haline gelirdi. \\
\hline 14 & 16. Bireyler geçmiş ve güncel sanat eserlerini tanırdı. \\
\hline 14 & 17. Sanat eğitimi okulla kalmazdı. \\
\hline 4 & 18. Bireyler sanat yaşını güzel atlatırdı. \\
\hline 9 & 19. Hayal güçleri ve yaratıcılığı gelişmiş bireyler olurdu. \\
\hline 24 & 20. Dünyaya estetik açıdan bakmayı bilen bireyler olurdu. \\
\hline 4 & 21. Bireyler müze alışkanlığı kazanırdı. \\
\hline 9 & 22. Çocukların zekâ gelişimini desteklerdi. \\
\hline 14 & 23. Bireylerin sanatsal tutumunu geliştirirdi. \\
\hline 4 & 24. Ülkemizde sanatçı sayısı artardı. \\
\hline 4 & 25. Bireyler üretme hazzını yaşardı. \\
\hline 4 & 26. Özgüvenli nesiller olur. \\
\hline 4 & 27. Özgür bireyler ve özgün eserler ortaya çıkardı. \\
\hline 14 & 28. Sanat derslerinin imajı değişirdi. \\
\hline 9 & 29. Öğrencilerin Görsel Sanatlar dersine ilgi ve tutumu değişirdi. \\
\hline 4 & 30. Araştırmayı seven bireyler olurdu. \\
\hline 9 & 31. Yeteneklerinin farkında olan bireyler yetişirdi. \\
\hline 9 & 32. Çocukların erken yaşta ilgi alanları ortaya çıkardı. \\
\hline 4 & 33. Sergi kültürü oluşurdu. \\
\hline 4 & 34. İnce ruhlu ve saygilı bireyler olurdu. \\
\hline 9 & 35. Sınıf ortamında öğrenci rolünden çıııp müze ortamında kâşif olurdu. \\
\hline 19 & 36. Kalıcı sanat eğitimi ortamı olurdu. \\
\hline 4 & 37. Zamanı iyi değerlendirmeyi bilen bireyler olurdu. \\
\hline
\end{tabular}

Tabloda görüldüğü gibi maddelere yoğunluk olarak katılımciların \%19'u 36. Maddeyi ifade etmiştir. 4 ve 20. Maddeler ise katılımcıların \%24'ü söylemiştir. Katılımcıların \%29'u 1 ve 6. Maddelerden bahsetmiştir. Bu bulgulara göre maddelerden 1, 2, 3, 4 ve 30. Maddelerden söylemde bulunan katılımcı görüş örneği: 
“Kesinlikle etkili bir şekilde sanata ilgi artardı. Sınıf ortamında dışarıdan bir örnek bile gelse öğrenci heyecanlanıyorlar. Gerçek esere bakıp hamuru işlese ona teknik olarak bilgi sağlar. Şövale görmeyen, bilmeyen öğrenciler orada form olarak bilgi edinir ve sanat terimlerine de aşina olup, öğrenir. Şahsen eleştirecek olsam kendimi bile 4 yıl eğitim yeterli olmadı. Maddî imkânsızlıklar içerisinde yağlı boya gördük ve yapmaya çalıştık. Sadece Çocuklara katkısı olmaz; ailelerin yanı sıra öğretmenlerin kendini geliştirmesi açısından da çok önemli olacaktır. Ve verilen eğitim de kalıcı olacaktır." (K1)

Maddelerden 1, 5, 6, 7 ve 15. Maddelerden bahseden katılımcı görüşü olarak: "Çok güzelmiş. Çok katkı sağlardı. Anasınıfından itibaren başlasa bu eğitim çocukların resimlerinde verdiği mesajlar bile yön alır gerçek eserler ile tanışan çocuklar bakış açıları gelişerek büyürdü. Ben çocukların bir sanat eserine anlamlandırmak için bakmasını istiyorum. Merak etmesini ve ilgi duymasını istiyorum. Eğer bu tür bir müze olsa yaşamının içine girer ve ona merak uyandırır keşfederdi." (K2)

Katılımcılardan (K8)'in söyleminde 13, 16 ve 20. Maddelerden bahsettiği görülmüştür: “Ülkemizde olsaydı çok güzel olur. Bilgi birikimine sahip çocuklar olurdu. Güncel bilgileri almaları, tarihi anlamaları açısından çok etkili. Sadece eski eserler değil, modern eserleri takip edip insanların dünyada neler yaptığını görme imkânı olurdu."

Bu bulgulara farklı bakış açısı olarak maddelerden 2, 3, 17 ve 18'e değinen katılımcının söylemi bu şekildedir: "Çocuk ve gençlik çağından kazanılan sanat kültürlerine sahip çıkması açısından çok önemli. 40 dakikalık süren derslerde bu kadar çok kazanımı sağlamamız imkânsız. Resim yaşı diye bir kavram var, bu sanat yaşını güzel atlamamış olan birey ileri yaşa geldiğinde bir ağaç, güneş ve ev çizmekle sınırlı bir hayal gücü oluyor. Bu yaş çok önemli kritik dönemde güzel eserlere ve yaratıcılık geliştirecek ortamlara maruz kalmayan bireyler ne saygı oluşturuyor ne de yaratıcılık. Boyayı tanımıyor bile bu çok üzücü." (K9)

Katılımcilardan (K11)'in görüşünde 36, 4, 35, 6, 23, 21. Maddelerden bahsetmiştir. Söylem olarak: “Kalıcı öğrenme sağlanırdı. Ebeveynler ile keyif alır ve unutmaz. Toplum açıcından çok önemli gelişmeler olurdu. Sınıf ortamında öğrenci rolünü alan çocuklar müze ortamında kâşif rolü olurdu. Gördüğü her esere sanatsal açıdan bakardı. Sınıf ortamında sadece gösterdiğine sanatsal bakarken müzede her eser onun için sanatsal obje olacağı için sanatsal bakış açısı gelişirdi. Okul atölyesine öğrenci mecburî geliyor ders süresini tamamlayıp gidiyor. Çoğu zaman malzeme bile getirmiyor. Ama müzeye istekli giden çocuk orada oyunlar ve etkinliklerle çok daha iyi zaman değerlendirir ve unutmaz. Müze bir alışkanlıktır."

Katılımcılara çalışmanın 3. Maddesi olarak "Çocuk ve Gençlik Sanat Müzesi olsaydı hangi kazanımlar sağlanırdı?" sorusu sorulmuştur. Verilen cevaplar ana çerçeve etrafında toplanmış 
maddeler listelenmiştir. Tablo 2'te katılımcıların toplanan verilerdeki maddelerden ne sıklıkla bahsettiği yüzdeler halinde verilmiştir.

Tablo 2.

Çocuk ve Gençlik Sanat Müzesi Olsaydı Sağlayacă̆ı Kazanımlara Yönelik Katılımcı Görüşleri

\begin{tabular}{ll}
\hline \multicolumn{1}{c}{$(\%)$} & \multicolumn{1}{c}{ Görüşler } \\
\hline 14 & 1. Tarihi, kültürel ve sanat değerlerini kazanır. \\
9 & 2. Sanat eserini tanır. \\
24 & 3. Bakış açısı gelişir. \\
4 & 4. Müzeyi tanır. \\
4 & 5. Müzenin görevlerini tanır. \\
4 & 6. Sanata saygı duyar. \\
9 & 7. Müzeyi yaşam biçimi olarak benimser. \\
14 & 8. Estetik kavramı oluşur. \\
4 & 9. Sanata duyarlılık kazanır. \\
14 & 10. Duygularını ifade eder. \\
4 & 11. Ön yargisız olur. \\
9 & 12. Empati kurar. \\
19 & 13. Eğitimde kalıcılık sağlanır. \\
4 & 14. Eleştirisel bakış açısını geliştirir. \\
4 & 15. Görsel sanat kültürü oluşur. \\
9 & 16. Biçimsel formları kazanır. \\
4 & 17. Değiştirme-dönüştürme (deformasyon) tanır. \\
4 & 18. Sanat akımlarını tanır. \\
9 & 19. 3 boyutlu eser ile 2 boyutlu eseri ayırt eder ve tanır. \\
4 & 20. Renk öğrenir. \\
4 & 21 Sanat eserinde dengeyi öğrenir. \\
4 & 22. Görmeyi öğrenir. \\
4 & 23. Motivasyon olur. \\
9 & 24. Illham alır. \\
4 & 25. Psikolojik tedavi sağlar. \\
4 & 26. Özgüveni gelişir. \\
4 & 27. Psiko-motor gelişimi artar. \\
4 & 28. Görsel uzamsal zekâsı gelişir. \\
4 & 29. Sanatsal gelişimi destekler. \\
4 & 30. Sanat tarihini öğrenir. \\
4 & 31. Öğretmenin gelişimini destekler. \\
4 & 32. Toplum açısından farkındalık olur. \\
4 & 33. Görsel sanatlar ders tutumu değişir. \\
4 & 34. Müze ile iletişim kurar. \\
4 & 35. Öğrenme isteği artar. \\
4 & 36. Sosyalleşir. \\
4 & 37. Yeteneklerini keşfeder. \\
4 & 38. Yaparak-yaşayarak öğrenir. \\
4 & 39. Hayal gücü gelişir. \\
14 & 40. Kendini tanır. \\
\hline & 2. Yaratıcılık gelişir. \\
\hline
\end{tabular}

1, 8, 10, 41. Maddelerden ise katılımciların \%14'ü söylemde bulunurken, \%19'u 13. Maddeden bahsetmiştir. 3. Madde olarak "bakış açısı gelişir" temasından ise katılımcıların \% 24 ' ü söz etmiştir. Temalara örnek olarak katılımcıların görüşlerinden 16, 19, 20, 21, 22. Maddelere dayanan söylem şu şekildedir: 
“3 boyutlu eser ile 2 boyutlu eseri ayırt eder ve tanır. Renk, biçimi tanır, Sanat eserinde denge unsuruna maruz kalarak bakış açısı ve ufku genişler. Görmeyi öğrenir. Görmeyi öğrenmek çok önemli. Bizim çocuklarımız görmeyi bilmiyor." (K12)

Bulgulara destek sağlayacak bir diğer görüşte 2, 13, 33. Maddelerden bahseden katılımc1 söylemi: "Sanat eserini tanırdı. Kitap gibi olmazdı, bunu asla unutmazdı. Sanat derslerine tutum değişirdi. Kazandırmak istediğin kazanımların hepsini kazanır ve akılda kalırdı." (K17).

Özel Eğitim Okulu'nda derse giren bir katılımcı 26, 37, 36, 23, 32. Maddelerden bahsederken şu şekilde ifade etmiştir: “Özel eğitim olarak düşünüyorum. Çocuklarda bazen çok farklı yetenekler ortaya çıkıyor ve onlar çocuğu ve aileyi hayata bağlıyor. Biz burada çocukların ürün çıkartmasının heyecanını yaşamasına tanık oluyoruz. Çok büyük değişimler oluyor çocuklarda. Bizi de heyecanlandırıyor. Bunu aileler ile yapsa umut kazanır ve hayatları anlamlanır. Özel eğitim için hayatlarını anlamlandırmak çok önemli." (K19)

Katılımcılarla yapılan görüşmelerde araştırmanın problemine ilişkin düşünce sürecini şekillendireceği ve açılım sağlayacağı varsayımıyla 4. Soru olarak "Müze eğitimin gerekliliği konusunda ne düşünüyorsunuz?" sorusu yöneltilmiştir. Katılımcıların hepsi "Kesinlikle gereklidir ve mutlaka olmalıdır" ifadesini kullanmıştır. Bu bağlamda öğretmen görüşlerinden gerekliliğine ilişkin alt görüşlerden ortak çıkarımlar alınarak Şekil 2'de görselleştirilmiştir.

Sanata ve tarihe bir adım daha yaklaşmasını sağlar.

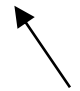

Tarihî, sosyal, ekonomik ve sanatsal alanda bilgi verir.

Sanatın ve tarihin gelişim aşamalarını öğrenmeleri açısından önem taşır.
Görsel belleğin oluşmasını sağlar.

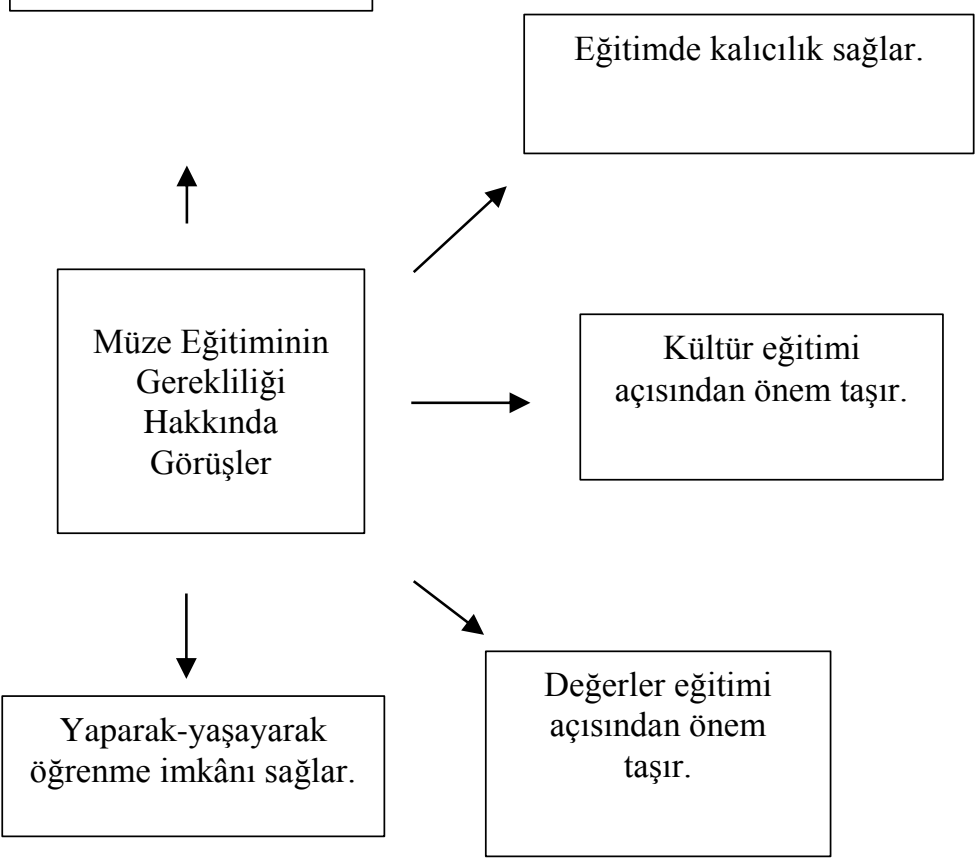

Şekil 2. Müze eğitiminin gerekliliği hakkında katılımcı görüşleri. 
Şekil 2'de görüldüğü gibi müze eğitiminin gerekliliği üzerine görüşler bulunmaktadır.

Örneğin; (K2): “Müze eğitimi geçmiş demek. İnsan ve kültür geçmişidir. İnsanlara anaokulundan itibaren müze eğitimi verilmesi gerekiyor. Bir Matematik, Türkçe dersleri kadar gereklidir." ifadesini kullanmıştır.

(K15): “Müze, tarih, geçmiş uygarlıklar ve sanat-sanatçı ve diğer bütün kültür ve kültür ögelerini içinde barındırır. Bize bu açlardan tatlar sunar, her esere bütüncül yaklaşımın farkındalığını arttırmak için müze eğitimi gereklidir."

Analizler sonucu ulaşılabilen bir diğer tema ise "Görsel belleğin oluşmasını sağlar." Az belirtilen bir görüş olmuştur. Buna bağlı olarak katılımcının söylemi: (K8): “Müze eğitimi çok gereklidir. Çocuklar müzelere gidip neye nasıl bakması gerektiğini öğrenir. Eski medeniyet eserleri ile günümüz modern eserleri de görmüş olurlar. Görsel bellekleri bu sayede gelişmiş olur. Bunu bire bir şahit olup göreceği sadece müzeler var."

Analizlerin sonucu ortalama söylemlerden bir diğer tema ise "Yaparak-yaşayarak öğrenme imkânı sağlar" kavramıdır bu söylemlerden örnek olarak: Müzelerde birebir öğrenci yaşantısı olacağından bireylerin deneyimlemesine çok katkı sağlar. Okullarla iş birliği içerisinde gidilirse okullarda verilen eğitimi somut hale getirir." (K18)

Katılımcılarla yapılan görüşmelerde 5. soru olarak "Müzede öğrencilere uygulama çalışması yaptırabildiniz mi? (Evet/ Hayır)" sorulmuştur. Şekil 3'te verilen cevapların yüzdeleri alınmış ve hazırlanmıştır.

\section{MÜZEDE ÖĞRENCILERE UYGULAMA ÇALIŞMASI YAPTIRABILDINIZ MI?}

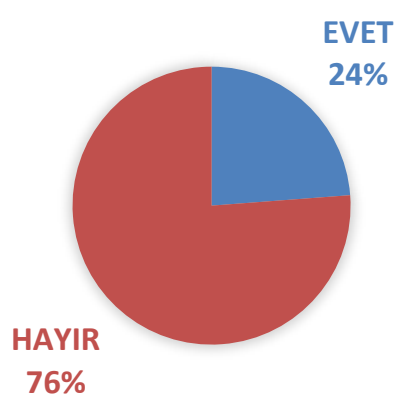

Şekil 3. "Müzelerde öğrencilere uygulama çalışması yaptırabildiniz mi?" sorusuna yönelik katılımciların görüşleri.

Katılımcılardan \%76'sı “Hayır" cevabını verirken; \%24'ü “Evet” söyleminde bulunmuştur.

Katılımcılara 6. soru olarak "Müzede öğrencilere sanat uygulaması çalışması yaptırdıysanız sanatsal etkinlik alanları yeterli mi?" sorulmuş ve görüşleri alınmıştır. 
Bu bağlamda "Mekânın önemi yok eğitimci önemlidir.", "Öğrencileri müzeye hiç götürmedim" ve "Fizikî şartlar yetersiz, alanlar çok dar" görüşleri çerçevesinde toplanılmış, katılımcıların verdikleri cevaplara göre kişi sayısına bağlı olarak yüzdeler hesaplanmıştır.

$\mathrm{Bu}$ verileri baz alınarak müzede öğrencilerin sanatsal uygulama çalışması açısından sanatsal etkinlik alanlarına ilişkin alt temalar öğretmen görüşlerine göre Şekil 4 'te görselleştirilmiştir:

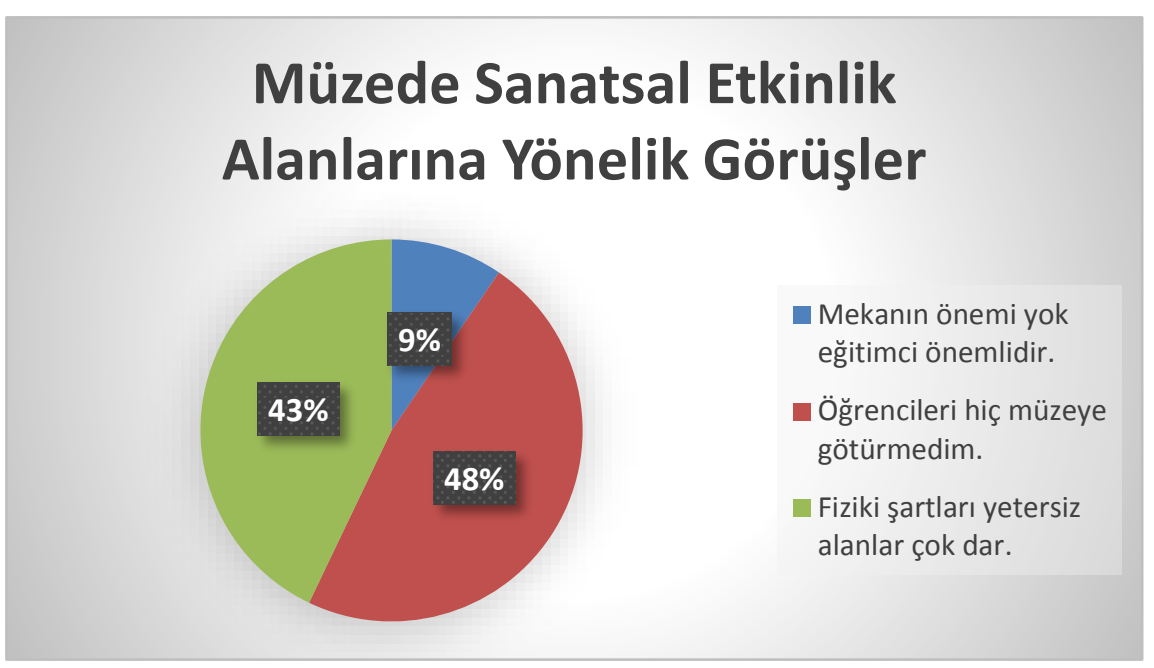

Şekil 4. "Müzede öğrencilere sanat uygulaması çalışması yaptırdıysanız sanatsal etkinlik alanları yeterli mi?" sorusuna katılımcıların görüşleri.

Şekilde 4'te görüldüğü gibi katılımcıların \%48'i “Öğrencileri müzeye hiç götürmediklerini” katılımcıların \%9'u "Mekânın ve fizikî şartların hiçbir önemi olmadığını" katılımcıların \%43'ü "Fizikî şartların yetersiz olduğunu koridorların ve alanların çok dar olduğunu" belirtmişlerdir.

“Öğrencileri müzeye hiç götürmedim.” teması altında görüşlerden Özel Eğitim İşs Okulu'nda Görsel Sanatlar öğretmeni olarak görev yapmakta olan katılımcı: “Özel eğitim alan öğrenciler için hiç uygun değil. Tabelalar, yönlendirme vs. gibi ve eğitim için oturacak yer bile yok." (K19) söyleminde bulunmuştur.

Bu alanda örnek görüşlerden: “Hiç götürmedim.” (K4)

"Fizikî şartlar yetersiz, alan çok dar" temasına örnek görüş olarak: "Sanatsal etkinlik alanlarının darlığından dolayı yaptırmadım; sürem kısıtlıydı ve 30 öğrenci ile dar olan koridorlarda oldukça zor oldu." (K1)

“Mekânın önemi yok eğitimci önemlidir" temasına örnek görüş olarak: “Elimizdeki imkânlar yeterli değil diyoruz hep; bunu demek çok kolay ve bu bir bahane. Her yerde sanat eğitimi verilebilir. Mekân önemli değil." (K16) belirtilmiştir.

Katılımcllara 7. madde olarak "Müzede sanat eğitiminde kuramsal ve uygulama çalışmalarının getirdiği kazanımlar hakkında düşünceleriniz neler?" sorusu yönlendirilmiştir. 
Katılımcıların verdikleri cevaplar maddeler halinde toplanmış ve Tablo 3 'te sunulmuştur.

Katılımcıların bu maddeleri desteklediğine göre yüzdeler alınmış ve belirtilmiştir.

Tablo 3.

Müzede Sanat Eğitiminde Kuramsal ve Uygulama Çalışmalarının Getirdiği Kazanımlara Yönelik Katılımaı Görüşleri

\begin{tabular}{|c|c|}
\hline$(\%)$ & Görüşler \\
\hline 14 & 1. Öğrencilerin bakış açısı gelişir. \\
\hline 4 & 1. Ortam değişikliği öğrenmeyi olumlu yönde geliştirir. \\
\hline 19 & 2. Öğrencilerin ilgi ve istediği artar. \\
\hline 4 & 3. Öğrencilerin Görsel Sanatlar dersine tutumu değişir. \\
\hline 9 & 4. Çok fazla duyuya hitap eder. \\
\hline 34 & 5. Öğrenimin kalıcılığı sağlanır. \\
\hline 4 & 6. 2 boyut ile 3 boyutlu çalışmaların farkını ayırt eder. \\
\hline 4 & 7. Görmek ve araştırma güdüsü artar ve esin kaynakları edinir. \\
\hline 9 & 8. Yaparak ve yaşayarak öğrenir. \\
\hline 9 & $\begin{array}{l}\text { 9. Disiplinler arası eğitim gerçekleşir buna bağlı başka alanlarda da eğitim } \\
\text { kazanılmış olur. }\end{array}$ \\
\hline 4 & 10. Sanat eserlerini tanır. \\
\hline 14 & 11. Öğrenci yeteneklerini keşfetmesinde yardımcı olur. \\
\hline 9 & 12. El becerisi gelişir. \\
\hline 19 & 14. Yaratıcı ve farklı düşünebilen çocuklar olur. \\
\hline 4 & 15. Keşfetmeyi ve özümsemeyi öğrenir \\
\hline 9 & $\begin{array}{l}\text { 16. Sanatın tüm alt dallarıyla etkileşim halinde olur. (Estetik, sanat tarihi, } \\
\text { uygulama gibi). }\end{array}$ \\
\hline 4 & 17. O eserin neden-niçin yapıldığını sınar ve uygulama ile kalıcı olur. \\
\hline 4 & 18. Müzeyi ve müze türlerini tanır. \\
\hline 4 & 19. En eski maddeye biçim verme yöntemlerini tanır. \\
\hline 4 & 20. Anatomiyi öğrenir. \\
\hline 9 & 21. Bask1 tekniklerini geliştirir. \\
\hline 14 & 22. Geçmişten günümüze sanatın değişimi konusunda fikir edinir. \\
\hline 14 & 23. Estetik algısı gelişir. \\
\hline 9 & 24. Tarih ve sanatın gelişimini öğrenir. \\
\hline 14 & 25. Küçük ve büyük kas motorları gelişir. \\
\hline 4 & 26. Üretmek ve yaşama amacını sorgular. \\
\hline 19 & 27. Empati kurar. \\
\hline 4 & 28. Tuval ve kâğıt gibi malzemelere hayal gücünü yansıtmayı öğrenir. \\
\hline 4 & 29. Müze gezisi kurallarını öğrenir. \\
\hline 4 & 30. Ruh hali gelişir. \\
\hline 4 & 31. Müfredatta verilen tüm kazanımları kazanmasını sağlar. \\
\hline 14 & 32. Sanata ve tarihe duyarlı olur. \\
\hline 4 & 33. Öğrenciler beyin fırtınası yaparlar. \\
\hline 4 & 34. Hayal kurar. \\
\hline 4 & 35. Yapılandırmacı öğrenimi destekler. \\
\hline 34 & $\begin{array}{l}\text { 36. Müzede gösterilen eserin sanatsal çalışması ile birçok alanda bilgi sahibi olur. } \\
\text { (Biçim formu gibi). }\end{array}$ \\
\hline
\end{tabular}

Katılımcıların \%14'ü 1, 12, 22, 23, 25, 32. Maddelerin üzerinde dururken katılımciların \%19'u 3, 14 ve 27. Maddelerin kazanım olarak katkı sağlayacağını söylemiştir. Katılımcıların \%34'ü ise 6 ve 36. Maddelerin kazanım sağlayacağı yönündedir. 
Bu bulgulara yönelik katılımcı örneği olarak: “Ereğli bölgesi için Hitit dönemi çok mühim. Ben İvriz Kaya Anıtı'nın rölyefini yaptırdım. Öğrenci rölyefi tanıdı; iki boyut üç boyut farkını ayırt etti; ifade ettiği mesajı açıkladı ve kazanım olarak ifade gücü gelişti. Tek bir eserde birçok kazanımı bu sayede verebildim." (K2)

Bu bulgularda bir başka söylemde: “Her şeyin uygulamasında algı ve anlamı değişir. Orada, görüş yerinde etkili olur. Tarihini öğrenir çocuk, orayı hisseder. Kendi potansiyelinde orada çalışmalar ve drama gösterileri olsa daha ilgi çekici ve kazançlı olur." (K5)

"Yaparak-yaşayarak öğrenme her zaman daha etkilidir. Orada bir seramik ürünlerini gördükten sonra deneyimlemesi çok daha güzel olur. El becerisi geliştirir. Görsel ve tarihî imkân sunan müzede yapma ve etkinlik imkânı olma görsel hafıza olarak sanatsal açıdan gelişim sağlar." (K6)

“Geçmişten günümüze sanatın değişimini fikir edinir. Eskilerden günümüze değişim ve farklılıklar edinir. Estetik algısı gelişir. Tarih ve sanat tarihi öğrenir. Sanatın dallarını öğrenir. Görsel sanatların sadece resim değil, aslında tarihle iç içe olduğunu görür. Yaratıcllık geliştirir. Küçük ve büyük kas motorları gelişir." (K10)

Tablo 3'te yer alan 36. Maddenin katılımcıların \%34'ünün bahsettiği müzede gösterilen bir eserin sanatsal çalışma sonrası o eserden edindiği kazanımlar toplanmış ve ortak değerler Şekil $5^{\prime}$ te verilmiştir.

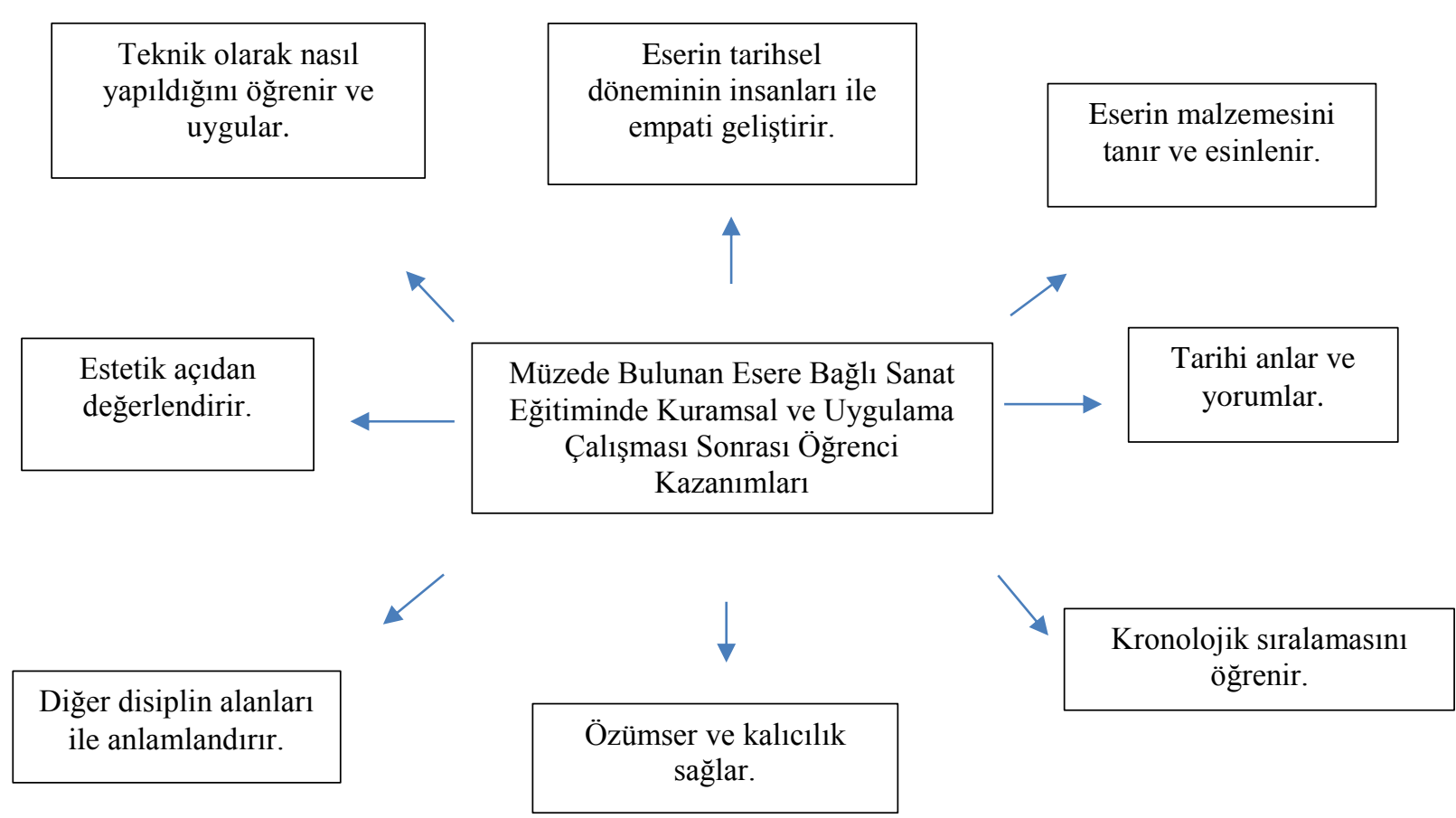

Şekil 5. Katılımcıların müzede bulunan esere bağlı sanat eğitiminde kuramsal ve uygulama çalışması sonrası öğrenci kazanımlarına yönelik görüşleri. 
Bulguya bağlı olarak örnek görüşlerden: "Yaratıcı ve farklı düşünen çocuklar olur. Keşfetmeyi ve özümsemeyi öğrenir. Gezip görmek yanı sıra orada bir eğitim olsa çok daha kalıcı olur. O esere bağlı olarak alacak olursak o eserde estetik, sanat tarihi iç içedir zaten sanatın tüm alt dalları birbiri ile ilişkilidir. Eğitimde bu unsurları beraber kullanırsak çocuk asla unutmaz." (K7)

“Çok etkili olur geçmişini ve bugününü birleştirir. Tuvale ve kâğıda hayal güçlerini aktarmayı öğrenir. Soyutlamayı öğrenir. İki farklı formları ve eserleri kafasında birleştirip kâğıda ya da çalışma alanına aktarır. Ve bu sayede çok fazla şey öğrenip uygular. Kalıcı olur. Bugün ve yarını kıyaslar." (K13)

Bulgulara katkı sağlayacak diğer görüş olarak: "Savaşlarda sanat eserlerine zarar verilmemiştir. Tarihe bakacak olursak sanata insanoğlu var olduğundan itibaren sayg1 duymuştur. Öğrencilerin bunu görmesi gerekir. Sanat; tarihi, coğrafî özellikleri, sosyal-kültürel özellikleri yansıtır. Bir tarihî eserde sanatı ve tarihi değil birçok boyutu öğretiriz." (K16)

Katılımcılara 8. Maddede “Öğrencileri müzeye götürmeden müze eğitiminin verilmesini doğru ve yeterli buluyor musunuz?" sorusu yönlendirilmiştir. Bu soru sonrası görüşler iki ana tema altında toplanmıştır. Bu iki tema katılımcıların sayısına ve görüşlerine göre yüzdelik alınarak Şekil 6’da gösterilmiştir.

\section{ÖĞRENCILERI MÜZEYE GÖTÜRMEDEN MÜZE EĞiTIMININ VERILMESINE YÖNELIK GÖRÜŞLER}

Doğru ve Yeterli Değil $\quad$ Doğru ve Yeterli

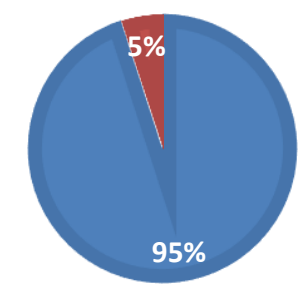

Şekil 6. Öğrencileri müzeye götürmeden müze eğitiminin verilmesine yönelik katılımcı görüşleri $(\%)$

Şekil 6’da görüldüğü üzere katılımcıların \%95'i öğrencileri müzeye götürmeden müze eğitiminin “Doğru ve yeterli olmadığı” kanısına varmışken katılımcıların \% 5 'i “Doğru ve yeterli” bulmuştur. Bu bulgudan "Doğru ve yeterli değil” temasına örnek söylemler olarak:

“Kalem olmadan çizim yapmak gibi, imkânsız." (K21)

“Kesinlikle doğru ve yeterli değildir. Yaşantı olmadan öğrenim olmaz." (K7)

"Doğru ve yeterlidir" temasına örnek katılımcı söylemi olarak: 
“Artık çevrimiçi müze gezileri var ve orada panoramik geziler düzenleniyor. Sadece açıklama tabelaları olsa çok daha etkili ve iyi olurdu. Eserlerin, görsellerin yanında açıklama levhası olsa daha iyi olurdu." (K4)

Katılımclara görüşmenin son Maddesi 9. Soru olarak "Müze eğitiminde internetten yararlanıyor musunuz?" sorulmuştur. Katılımcı cevapları 2 ana tema altında toplanmıştır.

Bulgulara göre temanın genel çerçeveleri "Yararlaniyorum" ve "Yararlanmiyorum" katılımcı cevaplarıdır. Ana tema halinde bulgunun maddeleri katılımcının katılım cevaplarına göre yüzdeler halinde alınmış ve Şekil 7' de verilmiştir.

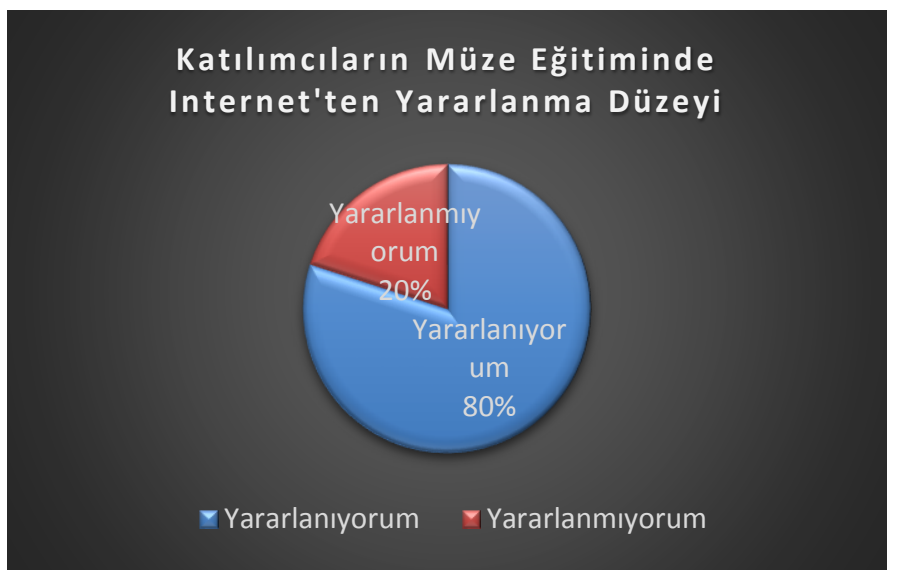

Şekil 7. Katılımcıların müze eğitiminde internetten yararlanma düzeyi (\%)

Şekil 7'de verildiği üzere katılımcıların \%20'si "Yararlanmıyorum" derken \%80'i "Yararlanıyorum" söyleminde bulunmuştur. Bu bulgulara yönelik iki ana tema içerinde katılımcıların \%80'inin müze eğitimini internetten yararlanırken nasıl yararlandığı Şekil 8'de verilmiştir.

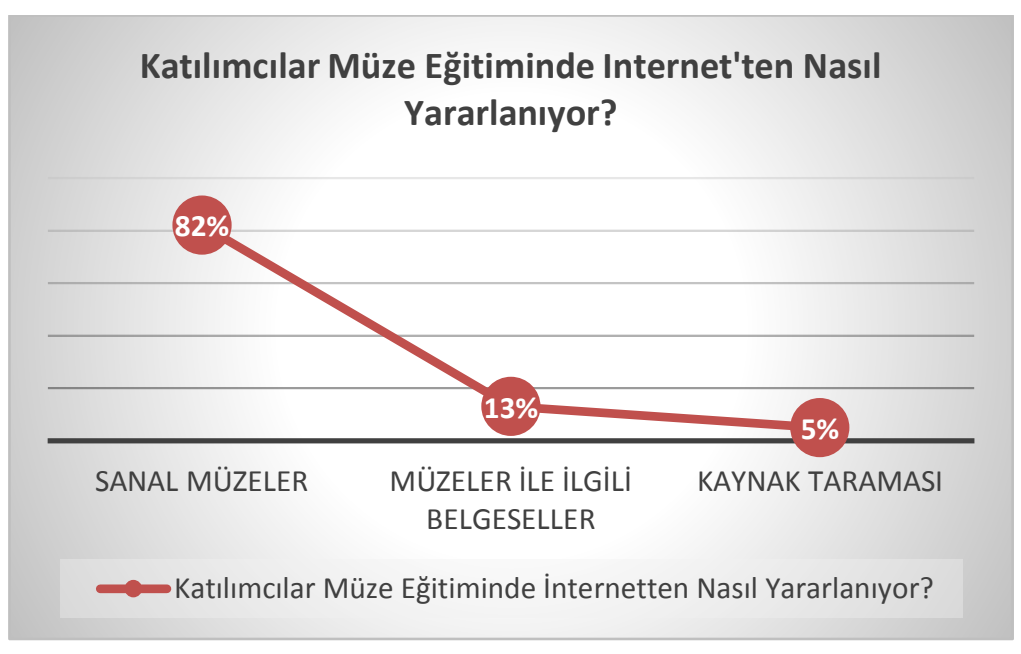

Şekil 8. Katılımcıların müze eğitiminden nasıl yararlandığına yönelik görüşleri (\%) 
Şekil 8' de "Yararlanıyorum" ifadesinde bulunan katılımcıların \%82'si "Sanal Müzelerden", \%13'ünün "müzeler ile ilgili belgesellerden" ve \%5'i “kaynak taraması" olarak faydalandıklarını ifade etmişlerdir.

Şekil 7 ve 8' de bahsi geçen örnek katılımcı söylemleri: "Şehrimizin kısıtlı imkânları olmasından dolayı yurt dışında bulunan müzeleri gezdirdim sanal olarak. Güzeldi." (K3)

“Sanal müzeden haberim yok, yararlanmadım hiç." (K17)

"Belgeseller gösterdim, orada anlattım ama havada kaldı diyebilirim." (K11)

"Kullanmıyorum. Teknolojiye karşıyım. Dokunarak yaşamaktan yanayım." (K7)

\section{TARTIŞMA}

Bu bölüm Çocuk ve Gençlik Sanat Müzesinin görsel sanat eğitimine katkısının ne olacağını yönünde Görsel Sanatlar öğretmenlerinin görüşleri ve ilgili literatürlerden derlemeler yapılırken dünyada bulunan örneklerle belirlemeye çalışan bu araştırmadan, elde edilen bulgulara ilişkin tartışmalar ve yorum içermektedir.

Çocuk ve Gençlik Sanat Müzesinin sanat eğitimine katkısı yolunda katılımcıların ülkemizde bulunmayan bu müzeden haberdarlı̆̆ını yorumlamak amacı ile sorulmuştur. Katılımcılara "Yayılması yeni sayılan Çocuk ve Gençlik Sanat Müzesi hakkında bilginiz var mı?" sorusu sorulmuştur. Katılımcı görüşleri üç temada birleşmiştir. Şekil 1'de bu başlıklar grafik olarak verilmiştir. 21 katılımcıdan 5 katılımcı "Bilgim var", 14 kişi “Bilgim yok" ve 2 kişi "Emin değilim" cevabını vermiştir. "Emin değilim" diyen katılımcıların bir sonraki soruya geçmeden tema ile ilgili yeterli tahminlerde bulunmayarak bilgisi olmadığı saptanmıştır. Katılımcılara bir sonraki temaya geçmeden bulgularda bahsi geçen Çocuk ve Gençlik Sanat Müzesi her katılımcıya aynı şekilde ifade edilmiş ve "Çocuk ve Gençlik Sanat Müzesi ülkemizde olsaydı sanat eğitimine katkısı ne olurdu?" sorusu sorulmuştur.

. Bu temada katılımcı görüşleri Tablo 1'de maddeler halinde verilmiştir. 21 katılımcıdan 1 katılımcı madde 5, 8, 11, 13, 15, 18, 21, 24, 25, 26, 27, 30, 33, 34, 37. Maddeleri vurgulamaktadır. 21 katılımcıdan 2 katılımc 3, 7, 9, 10, 12, 19, 22, 29, 31, 32, 35. Maddelerden söylemde bulunurken, 3 katılımcı 2, 14, 16, 17, 23, 28. Maddelerden bahsetmiştir. Katılımcılardan 4 kişi 36. Maddeden bahsetmiştir. 21 katılımcıdan 5 katılımcı ise 4 ve 20. Maddelerin üzerine dururken 6 katılımcıda 1 ve 6. Maddelerden bahsetmiştir.

Katılımcıların bulgulara göre en sık bahsettiği madde olarak bireyin sanata ilgisi artacağını ve bireylerin sanata bakış açısı değişeceğidir.

Müze Eğitimi Seminerleri'nde (2) yer alan tanıma göre ziyaretçilerin sanatsal yaratıcılık düzeylerini arttırmak için etkinlikler yapan Çocuk ve Gençlik Sanat Müzelerinin ziyaretçilerin 
öğrenme, yaratma, koleksiyon yapma ve sergileme aşamalarını öğretecek içindeki sanatçıları ortaya çıartmak için etkinlikler yaptığını bildirirken bu sayede çocukların ve gençlerin sanat ve sanatçı sevgisini aşıladığını söylemiştir. Bu müzelerin yaparak ve yaşayarak öğrenmeyi temel aldığını bu sayede sanat öğretim merkezi haline geldiğini savunur. (Onur, 2010, s. 95)

Mamur (2015)'e göre sanat eğitiminin günlük deneyimler ile verildiğinde görsel kültür ve eleştirisel bakış açıcı oluşumu oldukça fazla olacağını ve kültürel değer kazanımı olacağını savunur. Bu sayede işbirlikçi keşifler sağlanarak sanatın eleştirisel alanlarını, tarihsel ve bağlantısal aşamaları verilirken görsel araştırma sorgulama yapma imkânı için uygun koşulların bu müzede olduğunu savunur. Sanatsal uygulama şansları ile beceri gelişimi desteklenirken yaratıcı ifade gücünün artmasına olanak sağlayacağı ifadesinde bulunur.

Bu bağlamlarda katılımcı görüşleri Tablo 1'de ifade edilmiş olan maddeler literatürleri desteklemektedir. Örnek görüşler olarak: “Çok güzel olurdu. Çünkü yaşayarak, yaparak öğrenme ile kapsamlı bilgiler edinirdi. Oyun ortamı alanında uygulama yapma şansları olacak ve faydalı olacaktır." (K4)

“Çok güzel olurdu. Amerika'da başlayan bu müzeler yıllar önce ülkemizde olmaması büyük eksiklik. Günümüze taşımak yaşatmak, estetik değerler açısından da çok önemlidir. El beceri görsel sanat kültürü gelişir. Sanata sayg1 duyan çocuklar olurdu." (K6)

“Keşke ülkemizde ve şehrimizde olsaydı. Herkes biraz daha açılırdı. Bu şehirde herkes çok kapalı sanata ve kültüre bunun açılıp yaşatılması için yaşantı olarak özümsenmeli. Herkes biraz daha bakış açısı gelişmiş toplum olurdu. Deneyimleyen aile ve birey ürünleri ortaya çıkartması açısından çok önemli olur ve kaç yaşında olursa olsun bu deneyim sanata daha güzel bakar ve anlar. Kas gelişimini destekler. Müzeler daha aktif olsa çok daha iyi olurdu." (K7)

Dünyada bu alanında çalışmalar ve uygulamalar yapılmaktadır. Arizona Çocuk Sanat Müzesi bireylerin sanatsal gelişimde kritik zamanlarını önem vererek farklı sanat eserlerini profesyonel olarak tanıtır ve öğretir. Bu amaçta 5 yaş ile 100 yaşı hedef alan müze sadece çocuklara yönelik sanat eğitimine katkısını baz almamaktadır. Erken öğrenmeyi desteklemek, yaratıcı düşünceyi beslemek ve aileleri bu alanda geliştirmek ve müzeye çekmek için etkinlikler yapmaktadır. Müzede gerçekleştirilin her etkinliğin öğrenme başlıkları farklı disiplinler ile sanatın farklı alanlarına değinir. Örneğin sanatsal masal deneyimleri etkinliği yapmaktadır. Bu etkinlik çocukların dilsel gelişimini desteklemek, sanatın kavramlarına maruz kalmakla teknik olarak bilgi sahibi olmayı, kas motorlarının gelişmesini desteklemek ve sanat eserlerini deneyimlemeyi amaçlamaktadır (İ.D.E.A Museum, 2019). Müzenin sanat eğitimine katkısı etkinlik hedefleri ve varoluş amacında açıktır. Bu amaçlar bu araştırmanın katılımcı görüşlerini desteklemektedir. 
Müze Eğitimi Seminerleri 2 (2010) kitabında Doç. Dr. Müge Artarın bildirisinde seminer değerlendirmesinde (Onur, 2010, s. 69); araştırmadaki katılımcılara"Mardin'de bir Çocuk Sanatları Müzesi açılmasının nedenleri nelerdir?" sorusuna "Yaratıcı ve geniş bakış açılı bir biçimde çocuk yetiştirmenin daha kolay olacağı" görüşü bu araştırmanın katılımcıların görüşü ile örtüşmektedir.

Al-Radaideh (2012) çalışmasında sanat müzelerinin okul için bulunmaz bir imkân sağladığını ve gerçek eser ile karşılaşan öğrencinin sanatın disiplinlerini görme imkânı olduğunu savunur. Bu çalışma öğrencilere; sanat tarihi, eleştiri, estetik ve sanat üretimi imkânı ile dengeli işleyiş sağlayacaklarını ifade eder. Okulların yetersiz sanat eğitimi şartlarını müze aracılığı ile tamamlarken öğrencilerin duyarlılıklarını ve kendini ifade etme gücüne bağlı duygularını geliştireceğini ifade eder. Görsel düşünme becerilerinin gelişmesine katkı sağlarken sanata bakmayı, gelişim temelli cevap vermeyi artıracağını ve sorularla grup tartışmalarının gerçekleşmek için uygun ortam olduğunu savunur. Öğrenci kendi iç dünyasını yansıtıcı uygulamalar geliştirerek sanat hakkında konuşma becerilerini kazanacağını söyler. Yaratıcı düşünce berecileri gelişirken iletişim becerilerinin artacağını savunur. Öğrencileri sanatsal alanda gelişmek ile yeterli kalmayıp akademik alanlarda da etkisinin olacağından bahseder. Bu bulgular, katılımcıların görüşleri desteklemektedir.

MOCHA Çocuk Sanatları Müzesi ise düşük gelirli topluluklar, devlet ve özel okullara sanat eğitimi vermek amacıyla kurulmuştur. Sanatın çocukların yaratıcı düşüncesi ve bilişsel gelişimi üzerinde iyi yönde gelişim sağladığı kabul edilmiştir. Sanat etkinlikleri düzenleyerek sadece toplum ve çocuk değil eğitimci içinde sanat eğitimini güncel tutmaktadır (Museum of Children's Arts: MOCHA, 2019).

Çocuk ve Gençlik Sanat Müzesinin sadece toplum ve çocuklar için değil eğitimcilere katkısının önemli olduğu yönünde katılımcı görüşü olarak: “Çocukların yanı sıra öğretmenler gelişir. Öğretmenler kendilerini yenilerler. Biz böyle bir müze olsaydı ve bunu sürekli kullansaydık bizim işleyişimiz ve bakış açımız değişirdi. Yıllardır aynı yollarla eğitim veriyoruz. Önce aile, öğretmen yenilenir ve çocuk zaten yenilenmek zorunda kalırdı." (K16)

Dünya örneklerinden Nepal Çocuk Sanatları Müzesi olarak ülkelerinde bulunmayan sanat tesislerini ve atölyeleri olmamasından dolayı çocukların bu deneyimleri yaşamasını hedeflemişlerdir. Deprem sonrası yaraları sarmak amacı ile kurulan müze fizikî alanları olmamasına rağmen sanat etkinlikleri, oyunlar ve çeşitli ortamlar ile düşüncelerini ifade etmelerini sağlamaktadır. Çocuklar bu sayede kendilerini güvende hissettiklerini savunur. Çocuklar farklı kültür örnekleri gibi etkinliklerle sanatsal teknik öğrenirler. Eğitimini her alanda sağlayarak kültür ve teknik olarak Nepal'de sanat eğitimine katkı sağlamaktadır (Children's Art Museum of Nepal, 2019). 
Doğu Norveç Oslofjord Oslo Uluslararası Çocuk Sanatları Müzesi ise bölgenin sanat eğitimine katkısı açısından koruma, yaratma, biçimlendirme görevi üstlenmiştir. Bu alanda sanat eğitimine diğer müzelerden farklı olarak dijital sanat alanında katkılar ve dijital oyun masalları gibi etkinlik imkânları sağlamaktadır (Eastern Norway Oslofjord Oslo Internatıonal Museum Of Chıldren's Art, 2019). Çocuk ve Gençlik Sanat Müzelerinin sanat eğitimine katkısı yönünde katılımcı görüşlerinde dijital sanata yönelik görüş bildirimi olmamıştır.

Katılımcıların değinmediği bir diğer nokta ise sanat eğitiminde ekonomik sınıf farkının Çocuk ve Gençlik Sanat Müzeleri aracılığı ile kalkmasıdır. Çin Tayvan Çocuk Sanatları Müzesi yaratıcılığı ve estetik duyları teşvik ederken ekonomik sınıf farkını ortadan kaldırmayı hedefler (Children's Art Museum in Taipei, 2019).

CMA Çocuk Sanatları Müzesi dünyanın her yerinden çocuklarla sanat eğitimine katkı olarak çevirim içi farklı projeler ve temalar üzerine sanat paylaşımı yaparken ziyaretçilere; liderlik, sürdürebilirlik, nezaket gibi temelleri kazanılmasını sağlamaktadır (Children's Museum of the Arts New York, 2019). Çevrimiçi farklı kültürler ile sanat paylaşımı yapılması ve liderlik, sürdürebilirlik, nezaket gibi davranışlarında katkısı olacağını katılımcılar görüş beyan etmemiştir.

Dünyada Çocuk ve Gençlik Sanat Müzeleri sanat eğitimi açısından önem taşımaktadır. Bu önem müzelerin etkinlikleri ve bu alanda çalışmalarıyla ortaya koymaktadır. Katılımcılar ülkemizde Çocuk ve Gençlik Sanat Müzesi olsaydı çok güzel olacağını ve ihtiyaç olduğunu açıkça ifade etmişlerdir. Çocuk ve Gençlik Sanat Müzesinin sanat eğitimine katkısının neler olacağ 1 yönünde katılımcı görüşleri, ilgili literatürler ve çalışmalarla manidar ilişki vardır.

Katılımcılara sorulan 3. Madde olarak "Çocuk ve Gençlik Sanat Müzesi olsaydı hangi kazanımlar sağlanırdı?" sorusunun bulgularına yönelik tartışma ve yorum yapılacaktır. Bu maddede katılımcı görüşleri Tablo 2'de verilmiştir. Buna bağlı olarak 21 katılımcıdan bir kere tekrarlanan, 4, 5, 6, 9, 11, 14, 15, 17, 18, 20, 21, 22, 23, 25, 26, 27, 28, 29, 30, 31, 32, 33, 34, 35, 36, 37, 38, 39, 40. Maddelerdir. 21 katılımcıdan 2 katılımcı 2, 7, 12, 16, 19, 24. Maddelerden bahsetmiştir. 21 katılımcıdan 3 katılımcının bahsettiği maddeler ise 1, 8, 10, 41'dir. 4 katılımcı 13. Madde olan eğitimde kalıcılık sağlandığından bahsederken 5 katılımcı bakış açısını geliştireceğini savunur.

Mamur (2015) de bahsettiği müzeler ilk olarak deneyimlere dayalı eğitim verirken okulun dışında yaşanan deneyimin sanat eğitiminde görsel kültür kuramı olarak eleştirisel bakış açısı ile dünya deneyimlerimizi şekillendirmesine yardımcı olur demektedir. Müze eğitimi yaşantı sonucu kendilerini, kendi kültürlerini tanırken farklı kültürleri keşfedeceğini savunur. Bu bulguyu katılımcı görüşleri desteklemektedir. 
Katılımcıların bahsetmediği "demokrasi kültürünün kazandırılması" olarak bu alanda Ali Artun'nun (2018, s. 174) bahsettiği müzelerin halkın sahip olduğu en demokratik ve sosyalist kuruluş olduğundan bahseder. Halkın her kesiminin eşit bir şekilde faydalanabileceği örneğin 1950'ler Britanya' sında müzeler hiçbir fark gözetmeden asilzadesinden yoksul kesime kadar aynı oranla yararlanır. Herkes bu kamusal alanların sanatsal varlıklarından yararlanmasının demokrasi kültürünü kazandıracağını ve demokrasi bilincini sağlayacağını ifade eder.

Burnham ve Kai-Kee'nin (2015) Müze Dersleri Yorum ve Deneyim kitabında bahsettiği D’Amico'ya göre “Müze eğitiminin kalbi atölyelerden geçmektedir. İnsan nasıl yaratıldığını bilirse başkalarının yarattığı eserlere saygı duyar ve yetişkin olan dersler ise sanatçı yaratmayı değil geçmiş ve güncel sanat eserlerini anlayan bireyler yaratarak sanata saygı duymalarını sağlamaktır.". Müze Dersleri Yorum ve Deneyim kitabında Metropolitan Müzesi'nde bir programda öğrencilerin sevdikleri sanat eserini arayıp bulmalarını ve tarih içinde ruh eşlerini tanımalarını sağlamaktır. Bu sayede kendi sanatçı kimliklerinin güçlendirirken empati kurmalarını sağlamaktır. Bir geleneğe ait olma hissi uyandıracağından bahseder. Cleveland Museum of Art, keşfetme imkânının ziyaretçilere sağlanmasına dayalı bedenlerini kullanmayı ve baktıkları sanat eserinin hareketlerini inceleme fırsatı sunarak dans ve tiyatro etkinlikleri yapmaktadır. Bu müze ziyaretçilere görmeyi öğrenmeyi kazandırmak amacı duymaktadır. 1970'ler de önemsenen ve geliştirilen kazanım ise "Sanatsal farkındalık" olmuştur. Yenawine' nin buna bağlı olarak sanat eğitiminin sözsüz ve bilgi temeline dayanmadan sanatın kendi niteliklerini kullanarak renk, estetik algı, doku, mekân, çizgi gibi nitelikleri bir sanat eseri diğer sanat eserini tercüme edebilir demektedir (s. 84). Buna bağlı ziyaretçiler müze gezilerini o zamanlar dansçı ve müzisyen eşliğinde gezerek anlamlandırdığını savunur. Bu literatürü katılımcı görüşlerini desteklemektedir.

Karadeniz ve Çıldır'ın (2014) bahsettiği Tate Modern'nin programlarının amacı gençlerin sanatsal yaratıcılıklarını ve üretkenliklerini geliştirmeyi amaçladıklarını bu doğrultuda gerçekleşen etkinliklerde sanata ve sanat eserine ilişkin kendi duygu ve düşüncelerini ifade etmelerini sağlarken farkı kültürlerin sanatsal uygulamalarını tanımalarını bu uygulamalar ile ilham alırken özgün eserler ortaya koymalarını hedeflemektedir. Bu müzede sanat konusunda konuşmalarını ve düşüncelerini dışa vurmayı öğretmektedir. Bu müze etkinliklerinde sanat eserine bakarak kil çalışmaları yaparken bu eserin üzerine hikâye yazmaları istenerek disiplinler arası eğitim verilmektedir (s. 89). Literatürden elde edilen bulgular katılımcı görüşleri ile örtüşmektedir. Bir diğer bulgu olarak literatürde bahsi geçen Londra Docklans Müzesi'nin önceliklerinden engelli izleyicilerin müzenin her bölümüne erişim imkânı ile eğitim alanlarında ve galerilerde eğitim almasına olanak sağlanması ile katılımcı 19'un bahsettiği şu söylem desteklemektedir: 
“Özel eğitim olarak düşünüyorum. Çocuklarda bazen çok farklı yetenekler ortaya çıkıyor ve onlar çocuğu ve aileyi hayata bağlıyor. Biz burada çocukların ürün çıkartmasının heyecanını yaşamasına tanık oluyoruz. Çok büyük değişimler oluyor çocuklarda. Bizi de heyecanlandırıyor. Bunu aileler ile yapsa umut kazanır ve hayatları anlamlanır. Özel eğitim için hayatlarını anlamlandırmak çok önemli."

Onur'un (2012, s. 387) bahsettiği bulgu ise sanat müzelerinde genç ziyaretçilere etkileşimli deneyimler sağlama alanlarının sanatı yorumlamasına yardımcı olmasını ve kendi sanat çalışması yaratmasının imkânını sağlayacağı yöndedir.

Griffin (2004) sanat müzeleri ziyaretinde ve sanat çalışmasında öğrenci kazanımları olarak yeteneklerini keşfetmelerini sağlayacağını, başarı düzeylerinin ve estetik anlayışın artacağını, şimdiye kadar sanatsal üretime girmeyen öğrencinin sanatsal alanda üretim yapmak isteğinin artacağını, farklı sanat eserlerini tanıyacağını, çocuğun sanatla bağlantı kurma duygusunun geliştireceğini, kendi anlamlarını oluşturma yönünde kendisine güven duygusunun gelişeceğini, sanatsal ifade edebilirken eleştiri ve takdir edilmesi gibi beceriler üzerine sohbet edebilmesini arttıracağını, sanat eserlerini tartışma becerisinin gelişeceğini vurgular. Katılımcı görüşlerini bu bulgular desteklemektedir.

Katılımcı görüşlerinden literatürleri destek olarak örnek söylemler: “Vermek istediğimiz konuların kazanımlarını şu an sınıf ortamında verdiğimiz dersin çok daha fazlasını vermiş oluruz ve sadece ders kazanımları ile kalmaz. Estetik algı değişeceğini ve ilgi artacağını düşünüyorum. İstediğin her konu ve kazanımı orada istediğin gibi kazandırabilirsin. Bu şekilde çalışmalar çok güzel umarım bu çalışmalar uygulanır ve çok güzel olur. Bir anne baba olarak kendi çocuklarımdan gözlemliyorum; evde okulda öğrendiği etkinlikleri benimle yaptığı zaman çok daha etkili ve kazanımlar artıyor. Çocuklarım bu etkinlikle ebeveynle yaptığı etkinliği yıllar geçse unutmuyor ki bu müzelere ailelerle gidilse toplum olarak gelişmeler olacaktır. Toplumun sanata bilinci artacaktır. Derste benim anlatımım ile öğrenci benim algılarımla öğreniyor ama kendisi eseri görse kendi beyninde ve algısında farklı duyular bırakıyor ve farklı uyaranlara maruz bırakılıyor. Her zaman ilk temas kuran bireyin kendisinin olması her alan için en iyi durumdur." (K1)

“Hayal dünyası gelişirdi. Orada canlandırırdı. Drama yapardı mesela çocuğun uyarlama gücü gelişir ve onu ilişkilendirme açısından gelişirdi. Orada elinde bulunan yaptığı maketi sanatçı ile empati kurarak ben olsam böyle yapardım diye gerçek eserden yorumlamalar yapardı. Hem eser tanıyor hem yorumluyor hem eleştiriyor hem uyguluyor ve tartışıyor. Bunlar istenilen kazanımın ötesine geçerdi. Öğrenci bir heykeli taş olarak görmekten vazgeçerdi. Mersin'e geziye götürmüştüm öğrencileri mermer heykeli gören öğrenci "Bu taşı niye buraya koydular" dedi. Öğrencilerim 16 yaşındaydı ve ben bu çocuğu suçlamıyorum bu eğitimin eksikliğine 
yorumluyorum. Bu yaşa kadar bu çocuk bir şey görmemiş guaş boyayı bile bilmiyordu. Çocuğa katkısının en çok genel kültür olacağını düşünüyorum." (K2)

“Müze kültürü ile yetişen çocuk olsaydım daha farklı bir sanat eğitimcisi olurdum. Öğrenci öğretmen ve toplum açısından çok daha etkili olurdu. Çok büyük bir eksiklikle büyüdük ve büyüyorlar. Belki ilgi alanı var çocuğun ama sınıf ortamında 40 dakika içerinde bunu keşfetmek çok. Zor şartlarda sanat eğitimi vermek ve notlar ile sınamak sanat için yeterli değil. Bunu yaşam olarak görmesi farklı olurdu. Müzeye neler koyabilirsin bile bilmiyor çocuklar. Anlatıyorsun ve eve gidince unutuluyor anlatılan ama yaşasa çocuk onu ömür boyu onu davranış olarak sindirir. Yaşam biçiminde sanata yer verirdi." (K6)

“Görsel sanat kültürü oluşurdu. Biçimsel formları kazanırdı. Değiştirme-dönüştürme (deformasyon) tanır. Öğrenciye deformasyona uğramış bir eseri gösterdiğimizde bu ne hocam diyor. Bakış açısı kazanan öğrenci deformasyonu tanırdı. Çocukların algısı gelişir. Deformasyon algısı oluşması gibi. Sanat akımlarını tanır ve onları sanatsal açıdan değerlendirmeyi öğrenir." (K11)

“ 3 boyutlu eser ile 2 boyutlu eser ayırt eder ve tanır. Renk biçim görür. Sanat eserlerinde denge unsuruna maruz kalarak bakış açısı ve ufku genişler. Görmeyi öğrenir. Görmeyi öğrenmek çok önemli. Bizim çocuklarımız görmeyi bilmiyor." (K12)

Katılımcılar Çocuk ve Gençlik Sanat Müzesi ülkemizde olsaydı kazanımlar olarak ele alırken yaşadıkları bölgeye bağlı olarak öğrencilerin sanatsal gelişim olarak geri kaldıklarını vurgulamışlardır. Okul ortamında ders saatinin yeterli olmadığını bu eğitimi kendi şartlarında sinırlı derecede verdiklerinden bahsetmişlerdir.

Araştırmanın problemine ilişkin açılım sağlayacağı ve bu süreci yönlendireceğini varsayarak katılımcılara soru olarak “Müze eğitiminin gerekliliği konusunda ne düşünüyorsunuz?" sorusu sorulmuştur. Katılımcıların tamamının müze eğitiminin gerekli olduğu konusunda hem fikir olup detaylandıran cevaplar vermişlerdir. Katılımcılar müze eğitiminin neden gerekli olduğu konusunda görsel belleğin oluşmasını sağladığını, eğitimde kalıcılık sağladığını, kültür eğitimi açısından önem taşıdığını, değerler eğitimi açısından önem taşıdığını, yaparak-yaşayarak öğrenme imkânı sağladığını ve tarihî, sosyal, ekonomik ve sanatsal alanda bilgi verdiğini ifade etmişlerdir. Katılımcıların yorumlarından çıkarımlar olarak tarihî, sosyal, ekonomik ve sanatsal alanda bilgi verdiğine bağlı alt temalarsa sanata ve tarihe bir adım daha yaklaştıklarıyla sanatın ve tarihin gelişim aşamalarını öğrenme açısından önem taşıdığı konusuna çıkarımlar olmuştur.

Mardin Müzeleri Müze Eğitimi Seminerleri'nde (2) (Onur, 2010) Doç. Dr. Müge Artar'ın "Müzede Öğrenme" bildirisinde seminer değerlendirmesi olarak seminer sonunda katılımcılarla 
görüşme yapmıştır. 28 katılımcıya müzenin işlevleri, müze eğitiminin gerekçeleri ve katılımcılın müze eğitimi sürecinde yer almak isteyip istemedikleri ve bu görüşe göre nedenleri sorulmuştur. Mardin Müzesi Seminer Değerlendirmesi raporu ile Çocuk ve Gençlik Sanat Müzesinin görsel sanatlar eğitimine katkısı araştırması katılımcılarının müze eğitiminin gerekçeleri ile ilgili görüşleri örtüşmektedir. Müze eğitimi seminerinin bulguları ile bu araştırmanın ilk tema bulguları tartışıldığında;

1. (Seminer değerlendirmesi) Tarihî eserleri topluma iletmek, tanıtmak ve yaşatmak maddesi, geçmişi hatırlayarak tarih bilinci kazandırmak, kültürü tanımanın müzeler aracılığıyla olacağı maddeleri ile (bu araştırmanın teması 1. Bulgusu olarak) değerler eğitimi açısından önem taşıması, kültür eğitimi açısından önem taşıdığı, tarihî, sosyal, ekonomik ve sanatsal alanda bilgi vermesi, sanata ve tarihe bir adım daha yaklaşmasını sağladığı; sanatın ve tarihin gelişim aşamalarını öğrenmesi açısından önem taşıdığı temaları ile örtüşmektedir.

2. Birebir örtüşen madde olarak yaparak ve yaşayarak öğrenme imkân sağladığı görüşü de her iki araştırmada aynı şekilde ifade edilmiştir.

3. Eğitimin kalıcı olacağı maddesi her iki araştırmada ortak bulunan bulgular arasındadır.

4. Merak ve yaratıcılık güdülerinin bu yolla karşılanması maddesi seminer değerlendirme araştırmasında (s. 68) yer alırken bu araştırmanın müze eğitiminin gerekliliği konusunda katılımcı görüşleri olarak:

“Sanatsal açıdan ilgilerini çeker ve merak uyandırır. Müzedeki eserlerle birebir etkileşime geçer." (K3).

İlgi ve meraktan bahseden katılımcı yaratıcılıktan bahsetmemiştir. Katılımcılardan yaratıcılık olgusuna değinen olmamıştır.

Yapılandırmacı eğitim çerçevesinde müze eğitimi olarak eğitim, öğrenme ve anlama ancak gerçek deneyimler sonucu gerçek bilgiler üzerine yeni bilgiler gelerek sağlanır. Bu imkânlar için müze yerini dolduramayacak bilgi kaynağıdır. Yapısalcılığa göre bilgi nesneden deneyimler sonucu öğrencide oluşan şemalar ile öğrenme süreci kolaylaşır. Karşılaşılan sorunlara gerçek yaşam bağlamları ile farklı çözümler yaratabilmek ve diğer öğrenenlerle ya da uzmanlar ile iş birliği sürecinde koyabilecekleri en iyi çözümü sunmaları istenir. Yapılandırmacı yaklaşım yaparak ve yaşayarak öğrenmeyi destekler. Öğrencinin öğrenme sürecinde aktif rol alması gerektiğini savunur (Şar ve Sağkol, 2013). Bulgusu araştırmanın bu temasının alt başlıkları olarak yaparak-yaşayarak öğrenme imkânı sağlar ile örtüşmektedir. Katılımcı örnek görüşü olarak: 
“Müzelerde bireylerin deneyimlemesi yaşantı yoluyla öğrenme olacağından sanat eğitimine katkısı olacaktır. Okullarla iş birliği sağlansa okullarda verilen eğitimi somut hale getirir." (K18)

Bir diğer görüş olarak eğitim sisteminin bu alanda öğretmenlere çıkarttıkları zorluklardan bahseden katılımcı söylemi olarak: "Şu anki Millî Eğitim sisteminde müfredatta yer alan konudan uygulanabileceğini düşünmüyorum. Gayet gerekli ama izin işlemleri taşıma olmaması ve öğretmenlerin bunlarla uğraşmamasından dolayı bunlar güç duruma düşürülüyor. Ders saati içerisinde çok zor oluyor." (K1)

Katılımcllar müze eğitiminin gerekliliği konusunda hem fikir olurken alt temalarla literatür bulguları uyuşmaktadır. Fakat katılımcıların ifadelerinde bu alanda yeterli eğitim sağlayamadıkları görülmüştür. Alt sebepler olarak izinler gibi şartların zor olması yer alırken bir başka söylem olarak: “Müze eğitiminin verilmesi taraftarıyım ancak çocukları özendiremiyoruz. İlkokulda gitmiş öğrenci, ‘Gittik, hiçbir şey yok, sıkıldık hızlıca gezdik geldik.' Diyorlar. Müzenin eser doluluğuna da bakıyor bu. İmkânsızlıktan başka şehirdeki müzelere götüremiyoruz. Çocuklar da zevk alırdı. Buradaki müze çok küçük, orada ilgisiz personeli görüp dönüyoruz."

Söylem olarak Ereğli Müzesi'nin küçük olduğunu, eser sayısının az olduğunu, öğrencilerin sıkıcı olarak nitelendirdiğini ve bu olgunun katılımcı tarafından değiştirilemediğini vurgulamıştır. Bir diğer olgu olarak imkânsızlıklar nedeni ile müze eğitimini gerçekleştiremediğini söylemiştir. Bu imkânsızlıklardan dolayı müze eğitimini gerçekleştiremediğini ve bunun alt sebepleri olarak uygulama yetersizliği yerine mekân ya da eser azlığına bağlayan katılımcılara zıt düşen görüş olarak Rika Burnham ve Elliott Kai-Kee'nin (2015, s. 39) “Müze Dersleri Yorum ve Deneyim" kitabında bahsettiği olgu: “Eğitmenler olarak ilk görevimiz öğrencilerin dikkatlerini çekmektir. İlişkilendirmeyi sağlayacak bir yapıyı yaratmak ve insanları büyük eserleri değerlendirmeye ve anlamaya davet etmenin bir yolunu bulmak zorundayız." Bu söylem ile öğretmen görüşü örtüşmemektedir.

Alt nedenler ve bazı sebepler literatürler ile uyuşmazken genel çerçeve olarak müze eğitiminin gerekliliği konusunda literatürler ve araştırmanın bulguları arasında manidar bir ilişki vardir.

Öğrencilerin uygulama çalışma yapılabilirliğine yönelik katılımcı görüşleri ilgili araştırmalar tartışılacak ve yorumlandırılacaktır. Araştırmanın ana teması olan Çocuk ve Gençlik Sanat Müzesinin sanat eğitimine katkısına ulaşmak adına bu müze türlerinin müzelerde sanatsal uygulama çalışması yaptırması açısından yaş gruplarına göre sınıflandırılması ve alanlar sağlaması önceliklidir. 
“Müzede uygulama çalışması yaptırabildiniz mi?" sorusu sorulmuştur. Katılımcıların 16'sı "Hayır" cevabını verirken katılımcıların 5 tanesi "Evet" cevabını vermiştir (şekil 3). Bu maddede öğretmenlerin büyük çoğunluğu müzede uygulama çalışması yaptıramamıştır.

“Katılımcılara bu doğrultuda "Müzede uygulama çalışması yaptırdıysanız sanatsal etkinlik alanları yeterli mi? Sorusu sorulmuştur. Katılımcılardan uygulama çalışması yaptırmayanlar bu alanda görüşlerini bildirmiş ve bulgu olarak kabul edilmiştir.

Şekil 4'te gösterildiği üzere katılımcıların 21'inden 10'u “Müzeye öğrencileri hiç götürmediğinden" bahsederken 9 katılımcı "Fizikî şartların yetersiz olduğunu" beyan etmiştir. Katılımcılardan 2 kişi ise "Mekânın önemi yok eğitimci önemlidir” ifadelerinde bulunmuştur.

Müzede uygulama çalışması gerçekleştirmeyen (K18) söylemi: “Yaptırmadım, o açıdan bakmadım."

Katılımcı (K19) Özel Eğitim Okulu'nda görev almaktadır. Bu temaya yorum olarak: “Özel eğitimli öğrenciler için hiç uygun değil. Tabelalar, yönlendirme ve eğitim için oturulacak yer bile yok."

Bu bulgulara ek olarak Eğitim ve Müze Semineri (San, 2007, s. 35) Petra Zwaka'nın bildirisinden örnekle; Almanya'da 80'li yıllarda müzeler yeniden değerlendirilmiştir. Bu değerlendirmede müze nasıl bir yol izleyecekse karar vermeliydi. Branşına ve koleksiyonuna göre kendi durumunda eğitime yer verip vermeyeceğine ve bu doğrultuda eğitime yer verecekse nasıl bir imkân ve eğitim gerçekleştirmeye karar vermeliydi. Buna bağlı olarak müzeler ICOM (International Council of Museums) tavsiyeleri ile deklarasyonlarda eğitim politikalarını ve toplumsal işlevlerini değerlendirerek yol izlemeleri gerekiyordu.

Sözü geçen literatürde müzelerin hedef kitlelerine göre eğitim amaçlı olacaksa nasıl bir yol izleyeceği Almanya'da 80'li yıllarda karar verilmiştir. Bu doğrultuda hedef kitle; gençler ve çocuklar olarak belirlenen müzeler eser sergileme ve müze alanlarını nesnenin öğretebilmesi baz alınarak yerleştirmeler yapılmıştır.

Katılımcılardan "Mekânın önemi yok eğitimci önemlidir" görüşüne destek olarak Nepal Çocuk Sanatları Müzesi'ni örnek olarak verecek olursak deprem sonrası çocukların desteğe ihtiyacı olduğunu düşünen bir grup gönüllü mekânı olmayan bir müzede eğitimler vermektedir. Bu eğitimciler okullarda, kamu alanlarında ve bir mekân ile sınırlandırılamayacak her yerde etkinlikler yapmaktadır.

Londra Docklands Müzesi eğitim müzeleri olarak İngiltere' de bahsi geçen müzelerdendir. $\mathrm{Bu}$ müzede tam ve yarı zamanlı müze eğitimcilerinden oluşmaktadır ve her gün eğitim yapılmaktadır. Müze bebekler için oyun alanları ve okul öncesi eğitim alanları yer alırken eğitim 
odaları, sanatsal etkinlik alanları bulunmakla beraber engelli izleyiciler için tüm galeriler ve eğitim odaları onların ulaşabilmesi açısından oluşturulmuştur. Bu müze ziyaret açısından çok sayıya ulaşmaktadır. Müzeyi kurarken ulaşabilirliğinin ve mekân cazibesinin neden ciddiye alınması gerektiğini Londra Docklands Müzesi bir kez daha kanıtladı ifadesinde bulunmuştur (Karadeniz, Çıldır, 2014, s. 110-112).

Londra Docklands Müzesi'nin incelenmesinde uygulama alanlarının önemini vurgularken Nepal Çocuk Sanatları Müzesi'nde alanların sağlanabilir olduğu ve eğitimcilerin elinde olduğu vurgulanmaktadır. Müzelerin ne amaçla var oldukları konusunda çalışma yapmaları gerektiğini ve bu doğrultuda alanlarında etkinlik alanlarının göz önünde bulundurması gerektiği görüşü yukarıda bahsi geçen Eğitim ve Müze Semineri (San, 2007, s. 35) kitabında Petra Zwaka'nın bildirisinde açıktır.

Katılımcılara "Müzede sanat eğitiminin kuramsal ve uygulama çalışmalarının getirdiği kazanımlar hakkında ne düşünüyorsunuz?" sorulmuştur. Bu temaya detaylar olarak katılımcı cevapları tablolaştırılmıştır ve Tablo $3^{\prime}$ te görüşü tekrarlayan katılımcı sayısı baz alınarak yüzdelik olarak hesaplanmıştır. Bu tabloya bağlı olarak katılımcıların yoğunlukla üstünde durdukları maddeler şunlardır:

21 katılımcıdan 3 katılımcının bahsettiği başlıklar:

1. Öğrencinin bakış açısı gelişir. (1. Madde)

2. Öğrencinin yeteneklerini keşfetmesinde yardımcı olur. (12. Madde)

3. Geçmişten günümüze sanatın değişimi konusunda fikir edinir. (22. Madde)

4. Estetik algısı gelişir. (23. Madde)

5. Küçük ve büyük kas motorları gelişir. (25. Madde)

6. Sanata ve tarihe duyarlı olur. (32. Madde)

21 katılımcıdan 4 katılımcının bahsettiği başlıklar:

1. Öğrencinin ilgi ve isteği artar. (3. Madde)

2. Empati kurar. (27. Madde)

21 katılımcının 7 katılımcının bahsettiği başlıklar ise “Öğrenimin kalıcılığı sağlanır" (Madde 6) ve "Müzede gösterilen eserin kuramsal ve uygulama çalışması sonrası birçok alanda bilgi sahibi olurlar." (Madde 36)

Bu bulgulara dayanarak katılımcıların çoğunluğunun bahsettiği 6. ve 36. Maddelerdir. Bu maddelere dayanarak Şekil 5'te detaylandırılmıştır. Bu şablonda müzede kuramsal ve uygulama 
çalışması sonrası nesneye bağlı öğrenim olarak öğrenci “Teknik olarak nasıl yapıldığını öğrenir ve uygular", "Eserin tarihsel dönem insanları ile empati geliştirir". "Eserin malzemesini tanır ve esinlenir", "Estetik açıdan değerlendirir", "Diğer disiplin alanları ile anlamlandırır”, “Özümser ve kalıcılık sağlar.”, “Tarihi anlar ve yorumlar.”, “Kronolojik sıralamasını öğrenir” ve “Özümser ve kalıcılık sağlar." Olarak alt başlıklara katılımcı görüşleri indirgenmiştir.

Eğitim ve Müze Semineri (San, 2007, 147) Doç. Dr. Canan Dizdar Terwiel'in “Sanat Eğitiminde Bir Yöntem Olarak Müzelerden Yararlanma" başlıklı bildirisinde, Müze yaşantısı, sosyal, bireysel ve fiziksel boyutları, nesnelerle algılar ve ilgiler yoluyla etkileşim, gözlem yapma, düşünce ve duygularını ifade etme, hayal gücünü kullanma, kendi yaşamına bağlama, bilgilenme, müzenin mesajını görürken anlama, nesneleri okuma, kültürel değerleri ve yaşamı paylaşma, gerçeği arama, uygulamalar yapma ve değerlendirme gibi özellikleri barındırır. Müze yaşantısı kültürel mirası devam ettirmek, geçmişi ve geleceği anlamlı hale getirmek, eski eserleri korumak ve yaşatmak gibi görevleri vardır. Sanat eğitiminde belirli çevre ve kalıplardan gelen öğrenci modelinin bakış açısını genişletmekle alışık olmadığı dünyaya bakmayı sağlayabilmede geçmiş kültürlerin ve tarihî eserlerin irdelenmesinin yeri önemlidir ifadelerini kullanmıştır.

Bu temada bulguların desteklediği literatürlerden biri olarak Patterson Williams'ın 1982 yılında yayımladığı "Object- Oriented Learning in Art Museums" isimli makalesinde bahsettiği müzelerde nesne-odaklı öğrenme olarak nitelendirdiği metottan şöyle bahsetmektedir:

Bu öğretim metodu; Dört farklı şekilde aktif ilişki kurmaya teşvik edilmesini önerir. Bu temeller nesneye bakmak, kişisel tepkilerini anlamlandırmak, kültürel bağlamda sanatı düşünmek ve yargılamak temeline dayanmaktadır. Bu bağlamda nesneye bakmak duyu deneyimi sağlamasının yanı sıra en doğru ve aktif deneyimler nesneye bakmak ile olacağını savunur. Gerçek bir nesneye bakmak tüm duyularını harekete geçireceğinden bahseder. Müze ziyaretçilere bakmayı ve kişinin kendisine bakmayı öğretir. Nesneye doğru bakmayı öğretmek o nesnenin materyallerini, teknikler, konu, boyut, renk, doku ve bu kategorilerden her biri arasında ilişki kurmayı öğretir. Ziyaretçi ziyaretin doğasını anlarken kendi davranışını kontrol etmeyi öğrenir. Diğer Bağlamda kişisel tepkilerini anlamlandırmaktan bahseder. Buna bağlı nesneden bilgi sahibi olmayan bireye göre çok karmaşık geldiğini söyler. Nesne bireyler arasında alınan tepkilerin değişiklik gösterdiğini, kişide uyandırdığı hislerin farklılık gösterdiğinden bahseder. Sanat objesini bilmek ile buna dâhil olmak arasında fark kişinin deneyimlemesinden geçer. Bu yaklaşımda empati sürecinin oluşmasını ve kişinin kendi içsel hesabını oluşturacağını söyler. Eğitiminin kuramsal bilgi veren rehber ve eğitimci ile kalırsa yetersiz olacağını savunur. 3. Olarak kültürel bağlamda sanatı düşünmek olarak bahsetmiştir. Sanat eserini kültürel bağlamda düşünmek, bireyi, tekniklerini, kişiliğini, sosyal ortamı ve sahibini tanımaktan geçer. Bu nesneyi bir kişinin yaptığı akılda tutularak düşünülmelidir. Müzenin nesneleri ve bu bilgileri iletmek 
görevidir. Bu nesneye bağlı tarih, sanat tarihi, insan tarihi gibi bilgiler barındırır. Müze nesnenin kültürel olarak önemini anlatır. Nesneye bağlı müze eğitiminde bu maddede ziyaretçinin sorguladığını ve farklılıklarını yaşadığını bu sayede farklı bilgi türleri izleyici üzerinde etki oluşturduğunu savunur. Ziyaretçiler eserlere kültürel eser olarak nitelendirildiğinde birçok olgu ve bunlara bağlı hipotez oluşturur. Son olarak ele aldığı yargılar başlığında ziyaretçi görsel, zihinsel ve duygusal etkinlik türlerine katılması gerektiğini, öznel değer yargıları oluşturması gerektiği bu yargıların estetik, ahlaki yargılar olabileceğini söylemektedir. Müze ziyaretinin nesne eğitimi temeli olduğu ve bunun deneyimsiz olamayacağın söylemiştir (Williams, 1982).

Tablo 3'te bahsi geçen 35. Madde "Yapılandırmacı öğrenimi destekler" bulgusu Riedler (2016) “Sanat Müzelerinde Öğretme ve Öğrenme Kuramları ve Bu Kuramların Müze Uygulamalarını Oluşturma Şekillendirme" adlı makalesinde yapılandırmacı kuramı bilginin dışarıda olmadığı ve bilenden bağımsız olmadığını söyler. Dewey'in bahsettiği müzede de öğrenme toplumdan ve bilişsel süreçten bağımsız değildir. Bilişsel kavrayış ancak bireyin yaşantısı ve bu yaşantı sonucu yaşantıyı algılaması durumunda oluşur. Dewey için müze yaşantısı öğrenme için önemli yer almaktadır. (Riedler, 2016). Bu bağlamda katılımcıların görüşlerinin belirtildiği bu temada Tablo 3 ve Şekil 5'te verilmiş olan bulgular literatür bulgularını desteklemektedir.

Katılımcılara "Öğrencileri müzeye götürmeden müze eğitiminin verilmesini doğru ve yeterli buluyor musunuz?" sorusu sorulmuştur. 21 katılımcıdan 20'si “Doğru ve yeterli değildir" İfadesi derken 1 katılımcı sanal müzelerin bu süreçte yeterli olduğunu öne sürerken “Doğru ve yeterlidir" demiştir. Bu temanın alt temaları ile birlikte Şekil 6 'da gösterilmiştir.

Bu bulgularda katılımcıların çoğunluğu öğrencileri müzeye götürmeden müze eğitiminin verilemeyeceğini söylemektedir. Örnek söylem olarak: “Kalem olmadan çizim yapmak gibi imkânsız." (K21)

Müze pedagojisi müzede ve müze yoluyla "öğrenmek” anlamına gelmektedir.

Müzeler ve çocukların müzedeki yaşantılarını; öğrencilerin gözlemleme, sonuç çıkarma, incelerken sorgulama, eleştirel düşünmesi, ilham alıp yaratma gibi kabiliyetlerinin geliştirilmesine olanak sağlar. Müzelerde öğrenciler eserleri ve kendi yaşantılarını, gelişimsel seviyelerine göre, inanç ve değerlerine katarak yorumlar ve anlarlar (Ünal, 2012). Katılımcıların çoğunluğunun bu yönde görüşleri literatürleri desteklemektedir.

Katılımcılara son madde olarak "Müze eğitiminde internetten yararlanıyor musunuz?" sorulmuştur. Katılımcı cevapları 2 ana tema altında toplanmışlardır. Şekil 7'de gösterilmiş olan bulgularda 21 katılımcıdan 17 kişi "Yararlanıyorum" derken 4 kişi "Yararlanmadığıı" ifade etmiştir. Katılımcıların 17'si müze eğitiminde internetten nasıl yararlandığı konusunda görüşleri 
Şekil 17'de verilmiştir. 17 katılımcıdan 14 kişi "Sanal müzelerden yararlanıyorum" ifadesi kullanırken 2 katılımcı "Müzeler ile ilgili belgesel izletiyorum" söyleminde bulunmuştur. 17 katılımcıdan 1 katılımcı ise "Kaynak taraması" amacı ile kullandığını söylemiştir.

Sanal müzeler ile ilgili olarak günümüz müzelerinin hedef kitlelerini belirlemesi ve bu kitlelere iletişim olarak uzaktan öğretim ve yüz yüze eğitim olarak ikiye ayrılmışlardır. Uzaktan öğretim, sergiler, yayımları ödünç verme ve mobil müzeleri kapsarken, yüz yüze eğitim ise kişiler arası iletişime dayanan nesne çalışmaları (çizim, konuşma, uygulama gibi) drama ve atölyeler gibi etkinlikleri içermektedir (Hooper Greenhill'den aktaran Onur, 2012, s. 56).

Bir diğer bulgu olarak da Barlas Bozkuş'un (2014) bu alanda çalışmasında modern müzecilik düşüncesi ile gelişen sanal müzeler sınırları olmayan, 24 saat açık olan, her kuşak sanatçısına açık anlayışını sürdüren müzelerdir. Sanal müzeler kültürel değerleri uluslararası tanıtmak görevi üstlenmişlerdir. Bu müzelerin her zaman her yerde erişebilir olması ile koleksiyon olarak geniş birikime ait olması açısından diğer ülkeler ile kültürel paylaşımı arttıracağ1 yönündedir. Nesne bilgisi ve görsel olarak hafızanın kullanılmasına bağlı müze koleksiyonları sanal gerçeklik teknolojisi ile sanal olarak yeniden yapılandırılmıştır. Sanal müzeleri Internet ortamına aktarılan bilgiler ve sergiler farklı koşullar altında kullanabilir olarak görmektedir. Sanal müzeler dijital olarak var olan çoklu ortam ile sosyal etkileşim sistemi sayesinde görsele dayalı eğitim dizgisi oluşturmaktadır. Dünyada bu alanda canlandırma tekniği gibi teknikler ile etkileşimli ortam sağlayan birçok müze bulunmaktadır.

Twining'e (2009) göre sanal dünya, farklı eğitim modelleri için ideal araçtır. Fiziksel yeni öğrenme topluluğu oluşturmak zor ve pahalı olan bu dünyada, toplumun sanal müzelere kolay ulaşma imkânı sağladığını savunur.

Bulgulara ve katılımcı görüşlerine bağlı olarak müzelere gidemeyen, farklı deneyimlerden yararlanma imkânı olmayan eğitim kurumları için sanal müzeler kullanılabilirlik açısından değerlidir. Katılımcıların köy okullarında ya da imkânı olmayan okullarda çalışmalarından dolayı Internet, akıllı tahta gibi sanal eğitim imkanından da yararlanamadığını ifade etmişlerdir. 21 katılımcı arasından 13 katılımcının sanal müzeleri aktif olarak derslerinde yararlandıklarından verim aldıklarından ancak müzeye götürmek ile aynı etkiyi vermediğinden bahsetmişlerdir. 1 katılımcı “Öğrenciyi müzeye götürmeden müze eğitiminin verilmesini doğru ve yeterli buluyor musunuz?" sorusuna müzeye götürmek yerine artık çevirim içi müzelerin olduğunu ve bazı eksiklerin onarılırsa çok daha etkili olduğunu ifade etmiştir. Katılımcı 4'ün söylemi: “Artık çevrimiçi müze gezileri var ve orada panoramik geziler düzenleniyor. Sadece açılama yer alan tabelalar olsa çok daha etkili ve iyi olurdu. Eserlerin görsellerin yanında açıklama levhası olsa daha iyi olurdu." 
Bu alanda diğer görüş örnekleri olarak: “Elbette kullanıyorum. Sanal turlar gibi birçok şekilde. Dikkat çekti ama gidip görmek gibi olmadı." (K5)

“Evet, sadece internetten yararlanabiliyorum maalesef. Ama duyular da yetersiz kaliyor."

Müze eğitiminde Internet'ten yararlanmadığını söyleyen katılımcı görüşleri olarak:

"Kullanmıyorum. Teknolojiye karşıyım dokunarak yaşamaktan yanayım." (K7)

"Yararlanmadım, akıllı takta yok." (K15)

Müze eğitiminde internetten yararlanma düzeyleri okulların olanaklarına ve öğretmenlerin bakış açılarına göre değişmektedir. İlgili literatürlerde sanal müzelerin etkileşimli eğitim gibi kültürel arası iletişim açısından erişim kolaylığı sağladığı yönünde olumlu eleştiriler bulunmaktadir.

\section{SONUÇ}

Araştırmada nitel boyutta yarı yapılandırılmış görüşme tekniğinin uygulanmasıyla elde edilen bulguların çözümlenmesi sonucunda, çalışma grubu olarak Konya'nın Ereğli ilçesine bağlı resmî ve özel okullarda görev alan Görsel Sanatlar öğretmenlerinin, Çocuk ve Gençlik Sanat Müzesinin görsel sanatlar eğitimine katkısı hakkında görüşlerine ilişkin çeşitli sonuçlara ulaşılmiştır.

1. Çocuk ve Gençlik Sanat Müzeleri hakkında 21 öğretmenden 5 öğretmenin bu konuda bilgi sahibi olduğu sonucuna varılmıştır. 2 öğretmen "Emin değilim" ifadesi kullandıktan sonra bu alanda kavram çerçevesine göre farklı tahminlerde bulunmuş ve 2 öğretmenin de bu alanda bilgisi olmadığı sonucuna varılmıştır. Bu sonuçlar doğrultusunda çoğunluk olarak "Emin değilim" ve "Bilgim yok" ifadesi bulunan bu alanda 21 öğretmenden 16 öğretmenin Çocuk ve Gençlik Sanat Müzesi hakkında bilgisi olmadığı ve bilme oranının çok düşük olduğu görülmüştür.

2. Bu alanda aynı bilgilendirme yapılan öğretmenlere araştırmanın ana teması "Çocuk ve Gençlik Sanat Müzesi ülkemizde olsaydı sanat eğitimine katkısı neler olurdu?" sorusuna 21 görsel sanatlar öğretmeninden 37 ortak görüş bildirilmiştir. 37 görüş ilgili literatürleri desteklemektedir. Görüşlerin arasında en yüksek katılımlı, 6 öğretmenin ortaklaştığı "Bireylerin sanata ilgisinin artacağı" ve "Bireylerin sanata bakış açısının değişeceği" olmuştur. Bu görüşler ilgili literatürler ile örtüşmektedir. İlgili alan yazılarda "Sanat eğitiminin verilmesinde ekonomik sınıf farkının kalkmasını sağlaması", "Çevirim içi farklı kültürlerle sanat paylaşımının gerçekleşmesi" ve "Dijital sanat alanına katkı sağlaması" katkıları yer almaktadır. Bu katkılardan katılımcılar bahsetmemiştir. 
3. Dünyada Çocuk ve Gençlik Sanat Müzelerinin yeri ve önemi büyüktür. Devlete bağlı ve özel sayısız çocuk müzeleri yer almaktadır. Dünyada isim yapmış Çocuk ve Gençlik Sanat Müzelerinden bu araştırmada bahsedilmiş ve katılımcı görüşleri ile tartışılmıştır. Her müzenin amaçları ve hedef kitleleri değişiklik göstermektedir. Bulundukları bölgelere göre ihtiyacı karşılama amaçlı kazanımları ve hedefleri bulunmaktadır. Bu alanla ilgili olarak Çocuk ve Gençlik Sanat Müzesi ülkemizde olsaydı sanat eğitimine katkısına yönelik katılımcı görüşleri, dünyada bu alanda var olan müzelerin sanatsal etkinlikler gerçekleştirirken görsel sanat eğitimine katkısı açısından katılımcı görüşlerini desteklemektedir.

4. “Çocuk ve Gençlik Sanat Müzesi olsaydı hangi kazanımlar olurdu?" sorusuna 21 katılımcıdan 41 ortak görüş belirtilmiştir. Maddelere en yüksek katılımlar olarak 4 katılımcı 13. Madde olan "eğitimde kalıcılık sağlar"dan bahsederken 5 katılımcı "Bakış açısını geliştirir" olarak ifade etmiştir. Bu doğrultularda ilgili alan yazılar ile öğretmen görüşleri örtüşmektedir.

5. Müze eğitiminin gerekliliğine yönelik katılımcı görüşlerinin 21 katılımcının tamamı müze eğitiminin gerekliliğini belirtmiştir. Bu doğrultuda kavram içeriğine yakın görüşler bildirilmiştir.

6. 21 Görsel Sanatlar öğretmeni arasında müzede 16 katılımcının öğrencilere uygulama çalışması yaptırmadığı ve 5 katılımcının yaptırdığı bulgularına ulaşılmıştır. Bu bulgular beklenen sayının altında olduğunu saptarken 21 katılımcıdan 10 katılımcının müzeye öğrencileri hiç götürmediğini ifade etmiştir. 21 katılımcıdan 9 katılımcının fiziki şartlar yetersiz olduğunu ifade ederken 2 katılımının mekânın önemli olmadığını eğitimci ile bunun sağlanabilir olduğunu ifade etmiştir. Bu doğrultuda müzeye kendisi gidip veya öğrencileri götüren katılımcıların çoğunluk ortak görüşü "fizikî şartların yetersiz" olduğudur.

7. Katılımcıların yaklaşık yarısının müzeye gitmemiş olması araştırmada beklenen orandan farklı olduğu görülmüştür. Görüşme formunda yer alan “Müzede sanat uygulaması çalışması yaptırdıysanız sanatsal etkinlik alanları yeterli mi?" sorusuna Katılımcı 18'in "Yaptırmadım o açıdan hiç bakmadım" ifadesi gibi diğer ifadeler ile görsel sanatlar öğretmenlerinin çoğunluğunun müze eğitimi konusunda ilgisiz kaldıkları saptanmıştır.

8. Müzede sanat eğitiminde kuramsal ve uygulama çalışmalarının getirdiği kazanımlar doğrultusunda 21 katılımcıdan 36 görüş bildirilmiştir. Görüşler içeriğe uygun bulunmuştur. Bu yönde en yüksek ortak görüş içeren 21 katılımcıdan 7 katılımcı tarafından dile getirilen "Öğrenimin kalıcılığı sağlanacağı" ve "Müzede gösterilen eserin kuramsal ve uygulama çalışması sonrası birçok alanda bilgi sahibi olacağıdır". Bu araştırmada yer alan literatürlere 
bağlı Çocuk ve Gençlik Sanat Müzesinin varoluş amacı ve eğitim etkinlikler kapsamında amaçları alanında müzede sanat eğitiminde kuramsal ve uygulama çalışmalarının getirdiği kazanımlara yönelik görüşler örtüşmektedir. Nesne odaklı öğrenmede bahsi geçen kazanımlar ile katılımcıların Şekil 5'te gösterilen nesneye bağlı sağlayacakları kazanımların içeriğe uygun olduğu görülmektedir.

9. Öğrencileri müzeye götürmeden müze eğitimi doğru ve yeterliliği konusunda 21 katılımcının 20'si doğru ve yeterli olmadığı yönünde hem fikir olmuştur. Yalnızca 1 katılımcı sanal müzeler aracılığı ile bu eğitimi verdiğini kabul ederken sanal müzelerdeki eksikliği belirtmiştir. Bu bulgularda, literatürlerde belirtilen yaparak- yaşayarak öğrenmenin etkili olduğu yönünde içerik ile öğretmenlerin bu alan konusunda farkındalık sahibi olduğu görülmüştür.

10. Öğretmenlerin müze eğitiminde internetten yararlanma düzeyleri iki ana tema altında yüksek oranla 21 katılımcıdan 17 katılımcının internetten yararlandığı sonucuna varılmıştır. Internet'ten yararlanan öğretmenlerin yüksek oranla 14 katılımcı olarak sanal müzelerden yararlandığı ortaya çıkmıştır. Öğretmenlerin bu doğrultuda görüşleri ilgili literatürlerde sanal müzelerin kullanım amaçları ile örtüşürken bu alanda çevrimiçi sanat paylaşımları olarak yararlanmadığı sonucuna varılmıştır. Sanatsal paylaşımlar yapmadan sadece sanal müze gezileri ile müze eğitimi verdikleri görülmüştür. Dünyada bulunan Çocuk ve Gençlik Sanat Müzelerin çevrimiçi paylaşım ve eğitimlerinden bahsetmeyerek bu alanda bilgi sahibi olmadıkları görülmüştür.

11. Öğretmenlerin söylemlerine göre müze eğitiminde uygulama ve kuramsal eğitim alanlarının yetersiz olduğunu bu alanda bilgi sahibi olmadıkları sonucuna varılırken. Çocuk ve Gençlik Sanat Müzesinin ilgili araştırmalar doğrultusunda görsel sanatlar eğitimine katkı sağlayacağı sonucuna varılmıştır. Öğretmen, öğrenci, toplum açısından müzede sanat eğitiminin verilmesinde kazanımların sınıf ortamında verilen müze eğitimine oranla ilgili araştırmalar ve görsel sanatlar öğretmenleriyle görüşmeler doğrultusunda çok daha fazla olacağına ve bu alanda yaşantıya dönüşerek sanat eğitimine katkılarının çok yönlü olacağı sonucuna varılmıştır.

\section{ÖNERILLER}

1. Ülkemizde bulunmayan Çocuk ve Gençlik Sanat Müzelerinin açılması önerilmektedir.

2. Müzelerin içerisinde eğitim için atölyeler gibi sanatsal çalışmaların yapılabileceği hazır alanlar oluşturulabilir.

3. Bireylerin müzede bulunan eserlerin kopya nesnelerine dokunabilecek ve bu nesnelere bağl1 farklı sanatsal etkinlikler yapılabilecek alanlar sağlanabilir. 
4. Öğretmen yetiştiren yükseköğretim kurumlarında, Resim İş Eğitimi Programı dışında diğer alanlarda da Müze ve Eğitim dersleri yer alabilir.

5. Şu an görev yapmakta olan Görsel Sanatlar başta diğer branş öğretmenleri için Millî Eğitim Bakanlığında gerçekleştirilen müze eğitimiyle ilgili bilgi ve beceri tutumlarını geliştirici hizmet-içi eğitim programları ile eğitimler gerçekleşebilir.

6. Müzelerde çalışan personelin özellikle müze rehberlerinin müze pedagojisi alanında hizmetiçi eğitim programları ile eğitimler gerçekleşebilir.

7. Görev yapmakta olan öğretmenlere interaktif sanal müzelerinin kullanımı ile ilgili bilgilendirme içeren hizmet-içi eğitimlerin gerçekleştirilebilir.

8. Millî Eğitim Bakanlığında Görsel Sanatlar dersinin bir ders saati olarak yeterli olmadığı ve arttırması gerektiği önerilmektedir.

9. Millı̂ Eğitim Bakanlığı Görsel Sanatlar dersi programlarında yer alan kültürel miras alanında verilen ders saatini arttırılabilir.

\section{KAYNAKÇA}

Al-Radaideh, B. (2012). The contribution of art museums to art education. Journal of Social Sciences, $8(4), 505-511$.

Artun, A. (2018). Tarih sahneleri sanat müzeleri I müze ve modernlik, İstanbul, İletişim.

B. Bozkuş, Ş. (2014). Kültür ve sanat iletişimi çerçevesinde Türkiye'de sanal müzelerin gelişimi, The Journal of Academic Social Science Studies, 26(2), 329-344.

Burnham, R. \& Kai-Kee, E. (2015). Müze dersleri yorum ve deneyim, (A. Onacak, Çev.), İstanbul, Koç Üniversitesi.

Buyurgan, S., \& Buyurgan, U. (2012). Sanat eğitimi ve öğretimi, Ankara, Pegem.

Büyüköztürk, Ş., Çakmak, E., Akgün, Ö., Karadeniz, Ş., \& Demirel, F. (2016). Bilimsel araştırma yöntemleri, Ankara, Pegem.

Children's Art Museum in Taipei (2019). Müze hakkında genel bilgiler. http://artart.com.tw sayfasından erişilmiştir.

Children's Art Museum of Nepal (2019). Müze hakknda genel bilgiler. http://nepalcam.com sayfasından erişilmiştir.

Children's Museum of the Arts New York (2019). Müze hakkında genel bilgiler. https:// www.moma.org sayfasından erişilmiştir. 
Eastern Norway Oslofjord Oslo Internatıonal Museum Of Chıldren's Art (2019). Müze hakkında genel bilgiler. https:/ / www.barnekunst.no sayfasından erişilmiştir.

Griffin, J. (2014). Research on students and museums: Looking more closely at the students in school gruops. Published Online in Wiley, http:/ / dx.doi.org/ 10. 1002 / sce. 2018.

İ.D.E.A Museum (2019). Müze hakkında genel bilgiler. https://www.ideamuseum.org sayfasından erişilmiştir.

Karadeniz, C. (2009). Dünyada çocuk müzeleri ile bilim, teknoloji ve keşif merkezlerinin incelenmesi ve Türkiye için bir çocuk müzesi modeli oluşturulması, Yüksek Lisans Tezi, Ankara Üniversitesi Sosyal Bilimler Enstitüsü, Ankara.

Karadeniz, C., \& Çıldır, Z. (2014). Ingiltere'de müze eğitimi “Londra'dan izlenimler". Ankara, Kalem Kitap.

Mamur, N. (2015). Resim-iş (görsel sanatlar) öğretmen eğitimi “Müze eğitimi ve uygulamaları” dersinde görsel kültür kuramı. NWSA-Education Sciences, 1C0631, 10(1), 29-53.

Museum of Children's Arts: MOCHA (2019). Müze hakkında genel bilgiler. http://mocha.org sayfasından erişilmiştir.

Onur, B. (2012). Çă̆daş müze eğitim ve gelişim müze psikolojisine Giriş. Ankara, İmge.

Onur, B. (Ed.), (2010). Müze eğitimi seminerleri (2), Mardin Müzeleri, Ankara, Ankara Üniversitesi.

Riedler, M. (2016). Sanat müzelerinde öğretme ve öğrenme kuramları ve bu kuramların müze uygulamalarını oluşturma şekillendirme ve dönüştürmeye yönelik etkileri, Akdeniz Egĭtim Araş,tımaları Dergisi, 19, 61-78.

San, İ. (Ed.). (2007). Müze ve eğitimi seminerleri, Ankara, Kök.

Şar, E., \& Sağkol, T. (2013). Eğitim fakültelerinde müze eğitimi dersi gerekliliği üzerine, Hasan Ali Yücel Ĕ̈itim Fakültesi Dergisi, 20(2), 83-90.

Twinning, P. (2009). Exploring the educational potential of virtual words-some reflections from the SPP. British Journal of Educational Technology 40(3), 496-514 http://dx.doi.org/ 10.1111/j.1467-8535.2009.00963.x

Ünal. F. (2012). Observation of object preferences of interest by children aged between 4 and 8 in museums, Antalya Museum examples, Procedia-Social and Behavioral Sciences, 51, 362-367.

Williams, P (1982). Objeck-oriented learning in art museum, Roundtable Reports, 7(2), 12-15. 